\title{
Weather influences feed intake and feed efficiency in a temperate climate
}

\author{
Davina L. Hill ${ }^{* 1}$ and Eileen Wall* $†$ \\ *Animal and Veterinary Sciences Research Group, Scotland's Rural College, King's Buildings, West Mains Road, Edinburgh, EH9 3JG, UK \\ †ClimateXChange, High School Yards, Edinburgh, EH1 1LZ, United Kingdom
}

\begin{abstract}
A key goal for livestock science is to ensure that food production meets the needs of an increasing global population. Climate change may heighten this challenge through increases in mean temperatures and in the intensity, duration, and spatial distribution of extreme weather events, such as heat waves. Under high ambient temperatures, livestock are expected to decrease dry matter intake (DMI) to reduce their metabolic heat production. High yielding dairy cows require high DMI to support their levels of milk production, but this may increase susceptibility to heat stress. Here, we tested how feed intake and the rate of converting dry matter to milk (feed efficiency, FE) vary in response to natural fluctuations in weather conditions in a housed experimental herd of lactating Holstein Friesians in the United Kingdom. Cows belonged to 2 lines: those selected for high genetic merit for milk traits (select) and those at the UK average (control). We predicted that (1) feed intake and FE would vary with an index of temperature and humidity (THI), wind speed, and the number of hours of sunshine, and that (2) the effects of (1) would depend on the cows' genetic merit. Animals received a mixed ration, available ad libitum, from automatic feed measurement gates. Using $>73,000$ daily feed intake and FE records from 328 cows over 8 yr, we found that select cows produced more fat- and proteincorrected milk, and had higher DMI and FE than controls. Cows of both lines decreased DMI and fat- and protein-corrected milk but, importantly, increased FE as THI increased. This suggests that improvements in the efficiency of converting feed to milk may partially offset the costs of reduced milk yield owing to a warmer climate, at least under conditions of mild heat stress. The rate of increase in FE with THI was steeper in select cows than in controls, which raises the possibility that select cows use more effective coping tactics. This is, to our knowledge, the first longitudinal study on the effects of weather on FE. Understanding how
\end{abstract}

Received February 18, 2016.

Accepted August 21, 2016.

${ }^{1}$ Corresponding author: davina.hill@cumbria.ac.uk weather influences feed intake and efficiency can help us to develop management and selection practices that optimize productivity under unfavorable weather conditions. This will be an important aspect of climate resilience in future.

Key words: comprehensive climate index, crude protein intake, feed conversion ratio, metabolizable energy intake

\section{INTRODUCTION}

Producing enough food to meet the needs of the growing human population is an important challenge, especially given concerns over climate change. One way to address this challenge is in improving feed efficiency $(\mathbf{F E})$, the amount of meat or milk produced per unit of DM. Improving FE allows producers to increase their net output while minimizing feed costs and environmental impacts (Reynolds et al., 2011).

Individual cattle can vary in DMI above or below what is expected based on their growth rate or size (Herd and Arthur, 2009). They also differ in the amount of manure, methane, and carbon dioxide they produce for a given unit of DMI, and in their abilities to generate and conserve heat energy (DiGiacomo et al., 2014; Arndt et al., 2015). Animals that have a higher core body temperature, all else being equal (e.g., feed intake), are expected to direct a greater proportion of feed energy into metabolic heat production than into productivity, which reduces their production efficiency. Support for this comes from studies showing that beef cattle that are more efficient at directing feed to growth have lower rectal temperatures (Martello et al., 2016) and produce less metabolic heat (Basarab et al., 2003; Nkrumah et al., 2006) than less efficient animals. Similarly, dairy cows that convert feed into milk more efficiently produce less heat as a proportion of gross energy intake (Arndt et al., 2015) and have lower skin surface temperatures than less efficient cows (DiGiacomo et al., 2014). This suggests that efficient dairy cows might be less susceptible to thermal stress (stresses associated with high or low temperatures) than less efficient cows as a consequence of better thermoregulatory abilities in the former. 
Dairy cows, like other homeothermic animals, experience heat stress when environmental variables such as ambient temperature, humidity, solar radiation, and wind speed (WS) combine to exceed the body's thermoneutral zone, the range of ambient conditions at which metabolic heat production and heat loss are in equilibrium. High yielding dairy cows require high metabolic rates to support such yields, and this generates considerable metabolic heat (Kadzere et al., 2002). As metabolic heat production increases, a cow's thermoneutral zone shifts to a lower temperature range (Coppock et al., 1982). This means that higher yielding dairy cows experience heat stress at lower temperatures than lower yielding cows (Berman, 2005). In response to heat stress, cows reduce nutrient uptake, reallocate energy to thermoregulation, and experience changes in metabolism and endocrine function (Rhoads et al., 2009; Bernabucci et al., 2010; Renaudeau et al., 2012). These adjustments can lead to decreases in milk yield and quality (Bohmanova et al., 2007; Hammami et al., 2013; Hill and Wall, 2015).

The environmental conditions associated with heat stress can be quantified using temperature-humidity indices (THI), which are based on different weightings of ambient temperature and humidity. Evaporative cooling is the main means of energy loss in ruminants (Blaxter, 1962), but when ambient humidity is high, the process is hampered by a reduced moisture gradient between the air and respiratory surfaces. The thermal tolerance of cattle is also influenced by the velocity of ambient air (which influences rates of latent and sensible heat loss) and solar radiation (Dikmen and Hansen, 2009; Graunke et al., 2011; Hammami et al., 2013). This led Mader et al. (2006) to formulate a single metric that adjusts ambient temperature for relative humidity (RH), WS, and solar radiation, termed adjusted THI (hereafter $\mathbf{T H I} \mathbf{I}_{\text {adj }}$ ). The $\mathrm{THI}_{\text {adj }}$ explained milk traits more effectively than THI in a study carried out under temperate conditions (Hammami et al., 2013). Building upon these indices, the comprehensive climate index (CCI), which also adjusts ambient temperature for $\mathrm{RH}$, WS, and solar radiation, was developed specifically to consider the effects of both hot and cold environmental conditions on cattle, and was validated for its effects on DMI (Mader et al., 2010). Although the effects of heat stress on dairy cows have been well documented in tropical and subtropical regions (e.g., West et al., 2003; Dikmen and Hansen, 2009), a growing number of studies has reported declines in milk yield and quality with increasing THI in temperate regions (reviewed in Van Iaer et al., 2014), including the United Kingdom (Dunn et al., 2014; Hill and Wall, 2015), which has a maritime temperate climate with mild summers and winters.
Here we used 8 yr of data from a research farm in the south west of Scotland to investigate the effects of weather on DMI and the rate of converting DM to milk (FE) in Holstein Friesian dairy cows. In southern Scotland, temperatures are predicted to increase over the 21st century, especially in summer, with an expected mean daily maximum temperature increase of $4.3^{\circ} \mathrm{C}$ by the 2080s (Jenkins et al., 2009). The aims of our study were 3 -fold. First, we used Akaike's information criterion to compare 3 thermal indices: (1) THI, where WS and the number of hours of sunshine were controlled for statistically; (2) $\mathrm{THI}_{\mathrm{adj}}$; and (3) CCI. Because animals show a lagged response to THI with respect to milk yield (Bouraoui et al., 2002; West et al., 2003; Bertocchi et al., 2014), our second aim was to determine a biologically relevant timescale for quantifying the effects of thermal stress on DMI and FE. We did this by comparing the effects of weather on the day of feeding, mean weather spanning the day of feeding plus the $2 \mathrm{~d}$ before ( $3 \mathrm{~d}$ means), and mean weather spanning the day of feeding plus $6 \mathrm{~d}$ before $(7 \mathrm{~d}$ means). Third, we tested how genetic selection for milk traits influenced feed intake and FE (whereby a higher FE indicates a greater weight of fat- and protein-corrected milk produced for a given DMI) under varying weather conditions. We predicted that (1) as thermal indices increase, cows will reduce feed intake to decrease metabolic heat production, and reduce FE to divert more resources from milk production to thermoregulation. We also predicted that (2) the effect of heat stress on feed intake and FE would be greater in cows of high than average genetic merit because high yielding dairy cows generate more metabolic heat than lower yielding cows.

\section{MATERIALS AND METHODS}

\section{Subjects, Maintenance, and Data Collection}

The Langhill Holstein Friesian dairy herd was studied at Crichton Royal Farm, Dumfries (55 $04695^{\prime}$ N, $3^{\circ} 5905^{\prime}$ W) between March 2004 and July 2011 inclusive. The herd consisted of $\sim 200$ cows, of which approximately half remained indoors throughout the year, whereas the rest were grazed between April and October. For the remainder of the year, all cows were housed in distinct halves of the same building $(92.2 \times 26.7 \mathrm{~m})$ with access to a shared loafing area $(18 \times 26.7 \mathrm{~m}$ of the building's total space). The continuously housed cows were the focus of our study. They belonged to 2 genetic lines: select cows were bred to bulls of the highest genetic merit for kilograms of fat plus protein in the United Kingdom, whereas control cows were bred to bulls close 
to the United Kingdom average for those traits. Bulls were selected at random within a genetic line except that close relatives or sires known to yield calving difficulties were not used. Calving took place all year round, with most calves $(65.6 \%)$ being born between October and March of a given year. No differences were found in calving date between the 2 genetic groups within a given year (select: ordinal date 168.56 $\pm 7.78, \mathrm{n}=316$, control: $170.5 \pm 7.47, \mathrm{n}=352 ; \beta=1.97 \pm 10.74, t=$ $0.18, P=0.855$; linear mixed effects model controlling for lactation number and cow identity).

The cows were housed in a single building in conventional cubicle stalls $(210 \times 110 \mathrm{~cm})$ supplied with rubber mattresses covered with sawdust. The northernmost half of the northeast-facing side of the building was open sided above a 140-cm-high concrete wall. The southern half consisted of a gated section $(\sim 3 \mathrm{~m}$ wide) at either side of an indoor loafing area that was otherwise open to the elements and looked out to grazing fields. The remaining walls consisted of a concrete lower portion (190 cm high), and Yorkshire boarding from the concrete wall to the roof. The wooden panels $(115 \times 10 \mathrm{~cm}$ wide $)$ that made up the Yorkshire boarding were separated by $3-\mathrm{cm}$ gaps between consecutive panels, or a $70-\mathrm{cm}$ gap after every 16 th panel, to allow free airflow. No artificial ventilation was used. Pillars supported a gabled roof consisting of corrugated cement fiber with Perspex skylights.

Select and control cows received the same low forage diet consisting of $50 \%$ home-grown silage (grass, maize, and ammonia-treated wheat) and 50\% commercial concentrate feed (wheat grain, sugar beet pulp, rapeseed meal, soybean meal, wheat and barley distillers dark grains, and mineral and vitamin supplements) provided as a TMR (mean proportions of DM over a full lactation; Bell et al., 2011). The TMR was evenly distributed into $24 \mathrm{HOKO}$ automatic feed measurement gates (Insentec BV, Marknesse, the Netherlands), giving a ratio of 0.22 feeders per cow. These provided ad libitum feed throughout the day (except between 1145 and 1215 $\mathrm{h}$ when food residues were removed and fresh feed was supplied, and during milking). The number and identity of feeders and the amount of floor space available to the cows at feeding remained constant throughout the year. The HOKO data were recorded throughout lactation on a cycle of 3 consecutive days of measurement followed by 3 consecutive days without measurements. Water was available from troughs located at either end of the feeding passage. Cows were milked 3 times a day and received an additional $0.25 \mathrm{~kg}$ of concentrates in the parlor at each milking event (which is not included in any analysis presented here). Milk yield $(\mathrm{kg})$ was measured and summed for each day. Milk fat and pro- tein were measured 3 times a week (Tuesday afternoon, Wednesday morning, and Wednesday midday). Cows were weighed $(\mathrm{kg})$ after each milking event and scored for body condition (on an ordinal scale of $1-5$ with 0.25 intervals) once a week based on palpation of specific body parts (Lowman et al., 1976). Animals remained in the study for their first 3 lactations unless they were culled because of infertility or illness.

\section{Weather Data}

Daily measurements of dry bulb temperature $\left(\mathbf{T}_{\mathrm{db}}\right)$, WS, RH, and sunshine (summarized in Table 1) during the study period were downloaded from the British Atmospheric Data Centre website (UK Meteorological Office, 2012). All data were recorded at a single Meteorological Office weather station located on the grounds of the research farm ( $85 \mathrm{~m}$ northeast of the building housing the cows and $50 \mathrm{~m}$ above sea level). The $\mathrm{T}_{\mathrm{db}}$ and RH were point-sampled at $0900 \mathrm{~h}$, WS was measured $10 \mathrm{~m}$ above the ground between 0850 and 0900 $\mathrm{h}$ and expressed as a mean, and sunshine was measured using a Campbell-Stokes recorder and expressed as the number of hours over a 24 -h period (0000-2359 h). To see how measurements from the weather station reflected indoor conditions, we compared them to raw measurements of $\mathrm{T}_{\mathrm{db}}, \mathrm{RH}$, and WS made in the cattle building for a separate study (Haskell et al., 2013). Indoor data were collected between late April and early July 2009 and matched with Meteorological Office data for time and date.

Global solar radiation (GSR, the total amount of direct solar radiation and diffuse solar radiation falling on a horizontal surface in a given day) was estimated using the Angstrom-Prescott model (Angstrom, 1924; Prescott, 1940):

$$
\mathrm{GSR}=\mathrm{I}_{\mathrm{x}}\left(\mathrm{A}_{\mathrm{a}}+\mathrm{A}_{\mathrm{b}} \frac{\mathrm{nSun}}{\mathrm{N}}\right)
$$

where $I_{x}$ is extra-terrestrial radiation $(\mathrm{MJ} / \mathrm{m}$ per day), nSun is the number of hours of sunshine $(\mathrm{h} / \mathrm{d}), \mathrm{N}$ is day length (h/d), and $A_{a}$ and $A_{b}$ are site-specific empirical constants. We solved Equation [1] using the sirad package in $\mathrm{R}$ based on constants from the Meteosat Second Generation-based calibration (Bojanowski, 2013) and expressed the output as watts/meter ${ }^{2}$ per day.

The THI was calculated using

$$
\begin{aligned}
& \text { THI }=\left(1.8 \times \mathrm{T}_{\mathrm{db}}+32\right)- \\
& {\left[(0.55-0.0055 \times \mathrm{RH}) \times\left(1.8 \times \mathrm{T}_{\mathrm{db}}-26\right)\right]}
\end{aligned}
$$




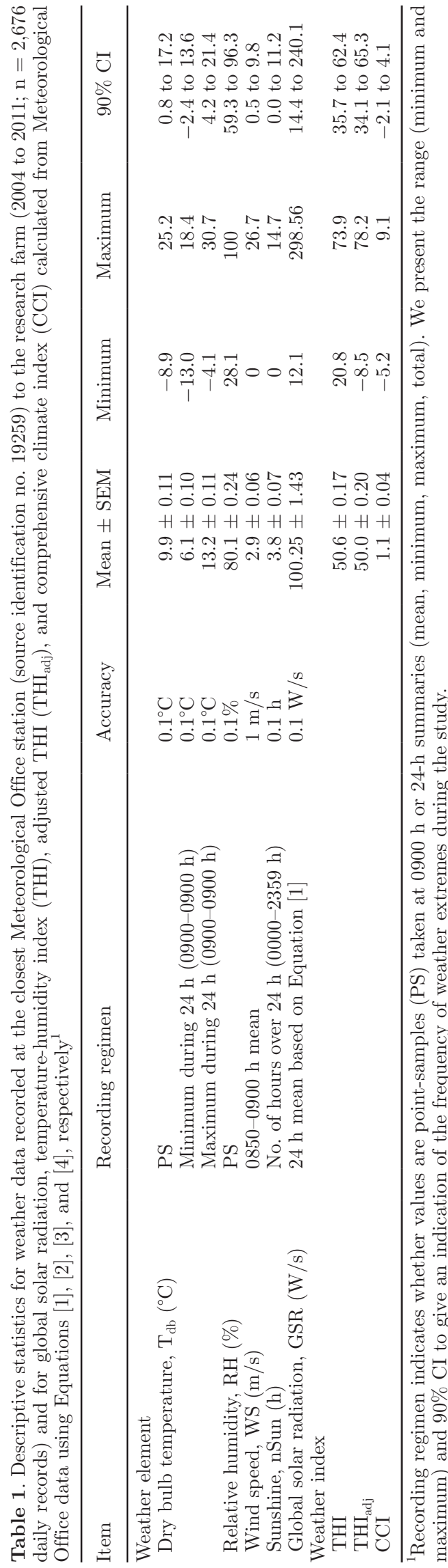

from the NRC (1971). Many formulations of THI have been devised, and we chose this one because it is used frequently in the agricultural literature (e.g., Hammami et al., 2013). We calculated adjusted THI using

$$
\mathrm{THI}_{\text {adj }}=\left[4.51+\mathrm{THI}_{2}-(1.992 \times \mathrm{WS})+(0.0068 \times \mathrm{GSR})\right]
$$

from Mader et al. (2006), where

$$
\mathrm{THI}_{2}=\left(0.8 \times \mathrm{T}_{\mathrm{db}}\right)+\left[\left(\frac{\mathrm{RH}}{100}\right) \times\left(\mathrm{T}_{\mathrm{db}}-14.4\right)\right]+46.4 .
$$

Finally, we calculated CCI using

$$
\mathrm{CCI}=\mathrm{RH}_{\mathrm{adj}}+\mathrm{WS}_{\mathrm{adj}}+\mathrm{GSR}_{\mathrm{adj}}
$$

from Mader et al. (2010). $\mathrm{RH}_{\text {adj }}, \mathrm{WS}_{\text {adj }}$, and $\mathrm{GSR}_{\text {adj }}$ are defined in the Appendix.

We calculated "moving" means for THI, nSun, WS, $\mathrm{THI}_{\text {adj }}$, and CCI over the 3 and $7 \mathrm{~d}$ before and including the test date (TD; the day of feeding) to allow the effects of weather to be compared over 3 timescales: TD, $3 \mathrm{~d}$ (where $3 \mathrm{~d}$ consists of TD, TD minus $1 \mathrm{~d}$, and TD minus $2 \mathrm{~d}$ ), and a week. Weather can have a lagged effect on biological traits, and the effects of a weather event can depend on its duration (West et al., 2003; Renaudeau et al., 2012; Hill and Wall, 2015).

\section{Animal Data}

We summed the total amount of fresh feed consumed per cow over each 24-h TD (00:00.00-23:59.59 h) to calculate her total daily feed intake. Summarizing data over a 24 -h period has the advantage that diurnal patterns in feeding behavior (Stamer et al., 1997) and management procedures do not need to be addressed. We calculated DMI $(\mathrm{g})$ based on a sample of TMR dried in a forced-air oven at $60^{\circ} \mathrm{C}$, crude protein intake (CPI, g) using the semi-automated Kjeldahl method (Association of Official Analytical Chemists, 1990), and metabolizable energy intake (MEI, MJ) from the prediction equation by Thomas et al. (1988). We refer to these 3 variables as feed intake. Finally, FE was estimated by dividing fat- and protein-corrected milk yield (FPCMY, kg) by DMI in kg where FPCMY is

$$
\begin{aligned}
{[0.337 \times} & \text { raw milk }(\mathrm{kg})]+[11.6 \times \text { fat content }(\mathrm{kg})] \\
& +[5.999 \times \text { protein content }(\mathrm{kg})]
\end{aligned}
$$


following Manzanilla Pech et al. (2014). As milk fat and protein were not sampled daily, we based our estimates on measurements from the closest sampling date to the TD.

Our data set contained 73,058 daily feed intake records from 328 cows on $2,427 \mathrm{~d}$ and 71,345 daily $\mathrm{FE}$ records from 328 cows on 2,418 d. Animals were $97.8 \pm$ 0.11\% (mean \pm SE; range 87.5-100) Holstein Friesian and ranged from 0 to 305 DIM. The number of daily records for each animal over her 3 lactations ranged from 11 to 438 (mean \pm SE: $222.7 \pm 6.74$ ) for feed intake and 11 to 432 (mean \pm SE: $217.5 \pm 6.59$ ) for FE.

\section{Statistical Analysis}

Data were analyzed using R. 3.1.1 ( $\mathrm{R}$ Core Team, 2014). We tested whether THI, WS, nSun, THI adj, and CCI changed over the study period using separate generalized least squares models for each weather element or index. These were fitted by restricted maximum likelihood (REML) using the nlme library in R (Pinheiro and Bates, 2014). We accounted for seasonal fluctuations in weather using harmonic regression and for nonindependence of weather from one day to the next by applying a first-order autocorrelation structure.

We compared the 3 timescales over which weather was summarized (TD, $3 \mathrm{~d}$ means, and weekly means) and the 3 methods of describing weather (hereafter called weather metrics; i.e., THI controlling for WS and sun vs. THI $_{\text {adj }}$ vs. CCI) using Akaike's information criterion (AIC). This approach is described in Hill and Wall (2015). Nonnested models can be compared using AIC provided that models be fitted to identical data sets (Burnham and Anderson, 2002). We therefore removed missing values using case-wise deletion to create 2 reduced data sets of 69,316 records $(94.8 \%$ of the total) for feed intake and 67,704 records $(94.9 \%$ of the total) for FE. The same numbers of individuals were included in the full and reduced data sets. We fitted the following linear mixed effects model with a fifth-order autocorrelation structure using maximum likelihood:

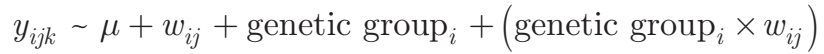

$$
\begin{aligned}
& + \text { lactation number } r_{i j k}+\mathrm{DIM}_{i j k}+\mathrm{LW}_{i j k}+\mathrm{CS}_{i j k} \\
& +\cos \left(\frac{2 \pi \mathrm{TD}}{365.25}\right)+\operatorname{sine}\left(\frac{2 \pi \mathrm{TD}}{365.25}\right)+\cos \left(\frac{2 \pi \mathrm{CD}}{365.25}\right)+\operatorname{sine}\left(\frac{2 \pi \mathrm{CD}}{365.25}\right) \\
& +\operatorname{animal~id~}_{j k}+\varepsilon_{i j k} \text {, }
\end{aligned}
$$

where $y$ was a single normally distributed response variable (DMI, CPI, MEI, or FE) for animal $i$ on test day $j$ that gave birth on calving date $k$ ); $\mu$ was the overall mean; $w$ was weather, expressed as one of the following: (a) THI + nSun + WS, (b) $\mathrm{THI}_{\text {adj }}$, or (c) CCI, experienced by animal $i$ over one of the 3 timescales (see above); genetic group ( $\mathrm{S}$ or $\mathrm{C}$ ) was a 2-level fixed factor for animal $i$ on day $j$; lactation number (1, 2 , or 3) was a 3-level ordered factor; DIM was days in milk (d 0-305 for feed intake and d 4-305 for FE; d 0 was the day of calving); CS was condition score [a proxy for the cow's energy reserves; a decline in CS suggests tissue mobilization to compensate for a negative energy balance (Bauman and Currie, 1980)]; and LW is live weight. Animal identity was a random factor (random intercepts only) and $\varepsilon$ was the unexplained variation for animal $i$ on test day $j$ that calved on date $k$. The TD (running test date, 1 to 2,676 ) and CD (running calving date, 1 to 2,945) were expressed as harmonic terms in the model to accommodate potential seasonal trends in management (e.g., stocking density) and photoperiod. The denominator of each sine and cosine term represents the periodicity of the waves. In this case, $365.25 \mathrm{~d}$ represents a wave for predictable annual variability (taking into account leap years). We tested for linear, quadratic, and cubic effects of all weather variables, DIM and LW, and linear and quadratic effects of CS. Weather variables, DIM, LW, and CS were mean-centered to reduce collinearity between higher and lower order terms of a given variable and to improve the interpretability of the estimates. We fitted nSun in the model rather than GSR because of the high correlation between GSR and THI $\left(\mathrm{r}_{\mathrm{p}}=0.641\right.$, $\left.t_{2392}=40.82, P<0.001\right)$ compared with nSun and THI $\left(\mathrm{r}_{\mathrm{p}}=0.318, t_{2392}=16.40, P<0.001\right)$. These methods generated 9 nonnested models $(3$ weather metrics $\times$ 3 timescales) per response variable. For each response variable, we determined the best model with respect to timescale and weather metric based on the lowest AIC, and considered 7 AIC units to be a meaningful difference (Burnham et al., 2011).

Models were re-fitted based on the full data sets using REML (retaining the same explanatory variables, including autocorrelation parameters) to obtain less biased estimates. To provide context for our results we repeated the THI+WS+nSun analysis with FPCMY (d 4-305 of lactation) as a (normally distributed) response variable using REML. We reached the final models using backward elimination of nonsignificant $(P \geq 0.05)$ interactions (higher order terms removed before lower order terms) and then main effects, retaining lower order terms where higher order terms were significant. We used differentiation of the regression equations to calculate turning points in polynomial relationships between weather and responses. For all models fitted by REML, we present estimates of model coefficients $(\beta)$ with standard errors, $t$-values, and $P$-values. All 
Table 2. Pearson correlations between weather variables and indices recorded at the research farm ${ }^{1}$

\begin{tabular}{|c|c|c|c|}
\hline Item & $r_{p}$ & df & $t$ \\
\hline $0900 \mathrm{~h} \mathrm{~T}_{\mathrm{db}}$ and mean $\mathrm{T}_{\mathrm{db}}$ & 0.945 & 2,419 & 6.3 \\
\hline THI and THI & 0.824 & 2,317 & 70.1 \\
\hline CCI and THI & 0.931 & 2,317 & 122.3 \\
\hline $\mathrm{CCI}$ and $\mathrm{THI}_{\text {adj }}$ & 0.823 & 2,317 & 69.8 \\
\hline
\end{tabular}

${ }^{1} \mathrm{~T}_{\mathrm{db}}$ is dry bulb temperature, THI is temperature-humidity index, $\mathrm{THI}_{\text {adj }}$ is THI adjusted for wind speed and global solar radiation, and CCI is comprehensive climate index. $P<0.001$ for all correlations.

statistical tests are 2-tailed, and significance is assumed at $P<0.05$.

\section{RESULTS}

\section{Weather at the Research Farm}

The $\mathrm{T}_{\mathrm{db}}$, THI, $\mathrm{THI}_{\mathrm{adj}}$, and CCI followed similar seasonal patterns, with peaks in July and troughs between December and February (Figures 1 and 2). The $\mathrm{T}_{\mathrm{db}}$ at $0900 \mathrm{~h}$ was $0.22 \pm 0.03^{\circ} \mathrm{C}$ warmer than mean $\mathrm{T}_{\mathrm{db}}$ calculated from daily minimum and maximum values $\left(t_{2419}\right.$ $=6.3, P<0.001$, paired test $)$. The $\mathrm{T}_{\mathrm{db}}$ at $0900 \mathrm{~h}$ and mean $\mathrm{T}_{\mathrm{db}}$ were closely correlated (Table 2 ). The THI and $\mathrm{THI}_{\text {adj }}$ showed a strong linear correlation (Table $2)$, although THI was higher than $\mathrm{THI}_{\mathrm{adj}}\left(t_{2318}=5.1, P\right.$ $<0.001$, paired test; Table 1, Figure 2). The CCI was closely correlated with THI, and slightly less so with $\mathrm{THI}_{\text {adj }}$ (Table 2). The THI at $0900 \mathrm{~h}$ was $>60$ units on

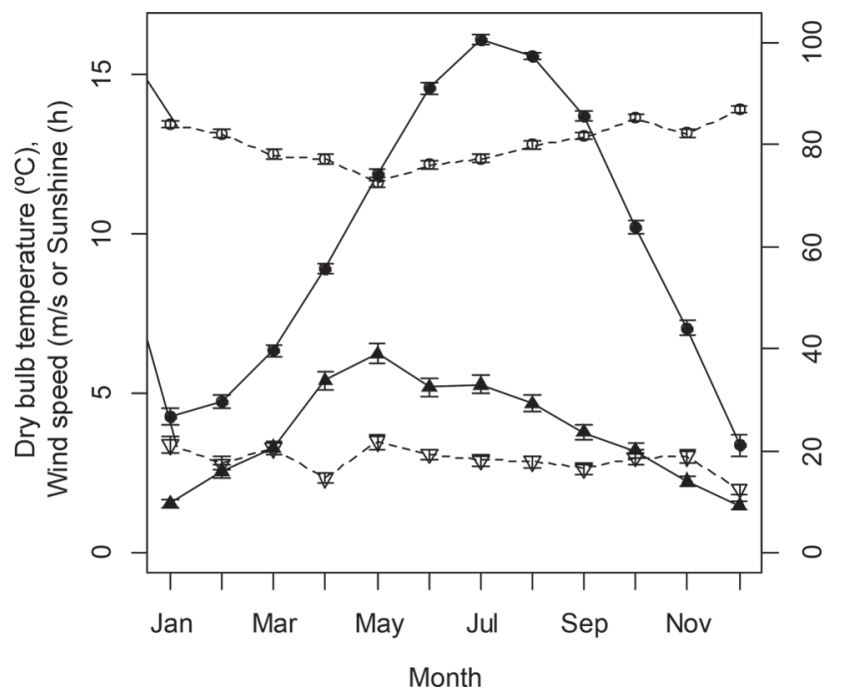

Figure 1. Mean monthly dry bulb temperature (closed circles) wind speed (open triangles), the number of hours of sunshine (closed triangles), and relative humidity (open circles) \pm 1 SE measured daily at the research farm, Dumfries, Scotland, during the study period (2004-2011). Weather values were point-sampled at $0900 \mathrm{~h}$ except for the number of hours of sunshine over $24 \mathrm{~h}$.
315 d over the study period ( $13.2 \%$ of TD), and $>70$ units on $6 \mathrm{~d}(0.3 \%)$; $\mathrm{THI}_{\text {adj }}$ at $0900 \mathrm{~h}$ was $>60$ units on $414 \mathrm{~d}(17.9 \%$ of TD) and $>70$ units on $27 \mathrm{~d}(1.2 \%)$. The nSun was greatest in May and lowest in December and January.

The THI, $\mathrm{THI}_{\mathrm{adj}}$, and CCI decreased over the study period (THI: $\beta=-0.0006 \pm 0.0002, t=2.8, P=0.005$; THI $_{\text {adj }}: \beta=-0.0008 \pm 0.0003, t=3.0, P=0.003$; CCI: $\beta=-0.0002 \pm 0.00005, t=3.5, P<0.001)$, but nSun $(\beta=0.0002 \pm 0.0001, t=0.18, P=0.854)$ and WS did not change $(\beta=0.00009 \pm 0.0001, t=0.88, P=$ 0.380 ).

No difference was observed in $\mathrm{T}_{\mathrm{db}}$ measured outdoors $\left(13.3 \pm 0.26^{\circ} \mathrm{C}, \mathrm{n}=75\right)$ and in the center of the loafing area $\left(13.3 \pm 0.26^{\circ} \mathrm{C}, \mathrm{n}=76 ; \beta=0.00002 \pm 0.05, t<\right.$ $0.01, P>0.999$, general linear model, controlling for date; $\mathrm{T}_{\mathrm{db}}$ data were square-root transformed to normalize), but conditions were cooler outside than in the middle of the feed face $\left(14.6 \pm 0.27^{\circ} \mathrm{C}, \mathrm{n}=76 ; \beta=1.6\right.$ $\pm 0.05, t=3.3, P=0.004)$. Outdoor $\mathrm{T}_{\mathrm{db}}$ measurements were strongly and positively correlated with measurements made in the loafing area $\left(\mathrm{r}_{\mathrm{s}}=0.94, t_{73}=24.6, P\right.$ $<0.001)$ and at the feed face $\left(\mathrm{r}_{\mathrm{s}}=0.94, t_{73}=23.6, P<\right.$ $0.001)$. The WS was higher outside $(3.14 \pm 0.21 \mathrm{~m} / \mathrm{s})$ than at the feed face $(0.07 \pm 0.03 \mathrm{~m} / \mathrm{s} ; \beta=3.7 \pm 0.42$, $z=8.9, P<0.001$, generalized linear model with Poisson errors, controlling for date) and the loafing area $(0.56 \pm 0.08 \mathrm{~m} / \mathrm{s} ; \beta=1.7 \pm 0.17, z=10.5, P<0.001)$. Outdoor WS was positively correlated with WS in the loafing area $\left(\mathrm{r}_{\mathrm{s}}=0.40, t_{73}=3.76, P<0.001\right)$, but

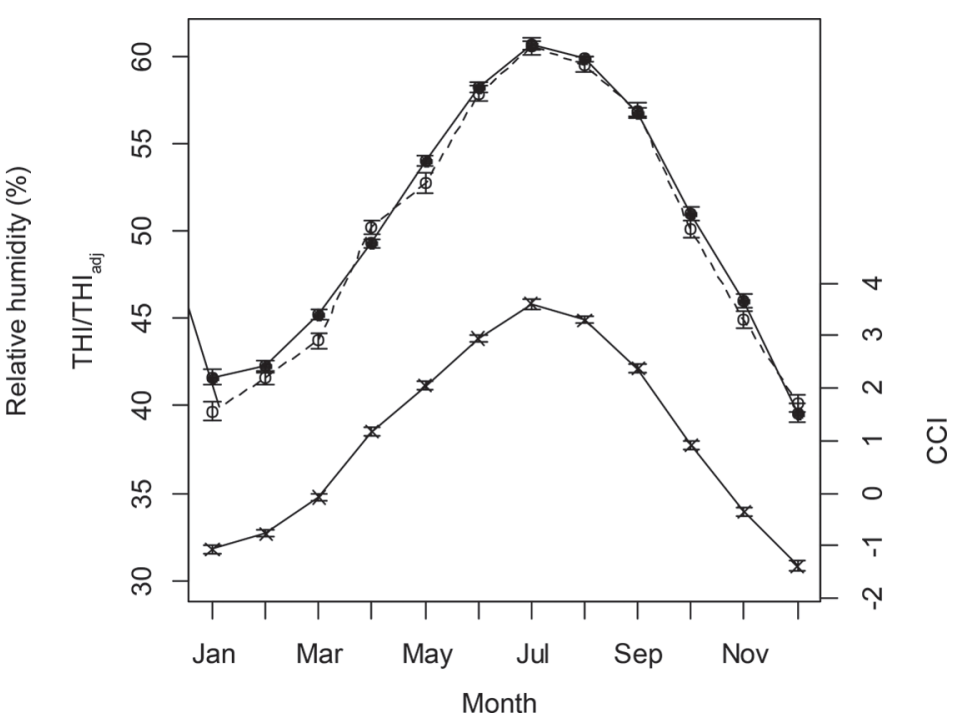

Figure 2. Mean monthly temperature-humidity index (THI; closed circles), THI adjusted for wind speed and global solar radiation ( $\mathrm{THI}_{\mathrm{adj}}$, open circles), and comprehensive climate index (CCI, crosses) $\pm 1 \mathrm{SE}$ based on values measured daily at $0900 \mathrm{~h}$ at the research farm, Dumfries, Scotland, during the study period (2004-2011). 
not at the feed face $\left(\mathrm{r}_{\mathrm{s}}=0.14, t_{73}=1.17, P=0.244\right)$. The RH did not differ between the 3 sites (feed face: $72.2 \pm 1.30 \%$, loafing: $70.3 \pm 1.30 \%$, outdoors: $72.1 \pm$ $1.32 \% ; F_{2,222}=0.66, P=0.520$, general linear model, controlling for date), and outdoor $\mathrm{RH}$ was positively correlated with $\mathrm{RH}$ at the feed face $\left(\mathrm{r}_{\mathrm{s}}=0.78, t_{72}=\right.$ 10.52, $P<0.001)$ and the loafing area $\left(\mathrm{r}_{\mathrm{s}}=0.84, t_{72}=\right.$ 13.06, $P<0.001)$.

\section{How Well Did 3 Weather Metrics Explain Feed Intake and Feed Efficiency?}

Maximum likelihood models testing for the effects of THI+WS + nSun explained feed intake and FE better than models testing for the effects of $\mathrm{THI}_{\mathrm{adj}}$ or $\mathrm{CCI}$ (Table 3). The CCI models fitted the data better than $\mathrm{THI}_{\text {adj }}$ models for DMI, CPI, and FE. The CCI and $\mathrm{THI}_{\text {adj }}$ explained MEI equally well. The THI, THI ${ }_{\text {adj }}$, and CCI were similar in the shape of their relationships with the 4 feeding traits, except at their lower extremes (Figure 3, Supplemental Figure S1; https:// doi.org/10.3168/jds.2016-11047). Indeed, at the lowest index values, $\mathrm{THI}_{\mathrm{adj}}$ and CCI followed different directions in their relationships with 2 feed intake traits (DMI and CPI): feed intake was highest at the lowest $\mathrm{THI}_{\text {adj }}$ values, whereas feed intake increased with CCI at low CCI values. By comparison, THI and CCI (which were closely correlated; Table 2) had the same sign for their relationships with these traits.

\section{Comparing Timescales for Quantifying Weather Metrics Using Maximum Likelihood}

Focusing on models for THI+WS+nSun, weather averaged over $3 \mathrm{~d}$ explained CPI and FE best, whereas weekly averages were best for MEI. Weekly and $3 \mathrm{~d}$ means performed equally well for DMI (Table 3). Models for $\mathrm{THI}_{\text {adj }}$ followed the same pattern as for THI+WS+nSun. For CCI, 3 d means explained CPI and ME data best, and weekly means were best for DMI and FE (Table 3). Overall, weather variables averaged over $3 \mathrm{~d}$ generated lower AIC values than those averaged over different timescales, so all further analyses were based on $3 \mathrm{~d}$ means.

\section{How Did Genetic Merit Influence Milk Yield and Feeding Traits?}

Cows of high genetic merit for milk fat and protein (select cows) produced more fat- and protein-corrected milk, consumed more feed (expressed as DM, CP, or $\mathrm{ME}$ ), and had a higher FE than control cows (Tables 4 and 5, Supplemental Table S1; https://doi.org/10.3168/ jds.2016-11047).

\section{How Did THI, Wind Speed, and the Number of Hours of Sunshine Influence Feeding Traits?}

The DMI, CPI, and MEI showed similar cubic relationships with THI: THI had little or no effect on feed intake at low THI values, followed by a decline in feed intake with increasing THI at higher THI values (Table 5, Supplemental Table S1, Figure 3a-c). The DMI reached a maximum of $21.35 \mathrm{~kg}$ in select cows and $19.18 \mathrm{~kg}$ in controls at 38.9 THI units. Between 55 and 65 THI units, declines in DMI averaged $80.01 \mathrm{~g}$ for every 1-unit increase in THI for both genetic groups (Figure 3a). This relationship resulted in a $5.31 \%$ decrease in DMI in select animals and $5.91 \%$ in controls between 65 THI units and peak DMI at 38.9 units. The

Table 3. Information-theoretic comparison of models fitted using maximum likelihood to compare the effects of weather index and measurement timescale on daily DMI, metabolizable energy intake (MEI), crude protein intake (CPI), and feed efficiency (FE) in 328 Holstein Friesian cows $\left(69,316\right.$ records for DMI, MEI, and CPI, and 67,941 records for FE) ${ }^{1}$

\begin{tabular}{|c|c|c|c|c|c|c|c|c|c|}
\hline Weather metric & Timescale & \multicolumn{2}{|r|}{ DMI } & \multicolumn{2}{|c|}{ MEI } & \multicolumn{2}{|c|}{ CPI } & \multicolumn{2}{|c|}{$\mathrm{FE}$} \\
\hline \multirow[t]{2}{*}{ THI, WS, sun } & TD & $\mathrm{e}$ & $1,292,608$ & $\mathrm{f}$ & 679,058 & $\mathrm{f}$ & 498,876 & $\mathrm{f}$ & 37,051 \\
\hline & Week & $\mathrm{a}$ & $1,292,263$ & $\mathrm{a}$ & 678,720 & $\mathrm{~b}$ & 498,641 & $\mathrm{~b}$ & 36,917 \\
\hline \multirow{2}{*}{$\mathrm{THI}_{\text {adj }}$} & TD & $\mathrm{g}$ & $1,292,672$ & $\mathrm{~h}$ & 679,124 & $\mathrm{~h}$ & 498,998 & $\mathrm{~h}$ & 37,081 \\
\hline & $3 \mathrm{~d}$ & $\mathrm{~d}$ & $1,292,459$ & de & 678,922 & d & 498,733 & e & 37,010 \\
\hline \multirow{2}{*}{ CCI } & $3 \mathrm{~d}$ & $\mathrm{c}$ & $1,292,408$ & d & 678,917 & $\mathrm{~b}$ & 498,640 & d & 36,991 \\
\hline & Week & $\mathrm{b}$ & $1,292,401$ & e & 678,925 & $\mathrm{c}$ & 498,713 & $\mathrm{c}$ & 36,955 \\
\hline
\end{tabular}

${ }^{1}$ Models are ranked from best (lowest Akaike information criterion, AIC) to worst within each feeding trait; a represents the most favorable rank, and different lowercase letters indicate meaningful differences ( $\geq 7$ AIC units). Models are based on Equation [6] and differ from each other only in the terms indicated in the first column. THI is temperature-humidity index, WS is wind speed; THI adj is THI adjusted for wind speed and global solar radiation; CCI is comprehensive climate index. TD is test date. 
a

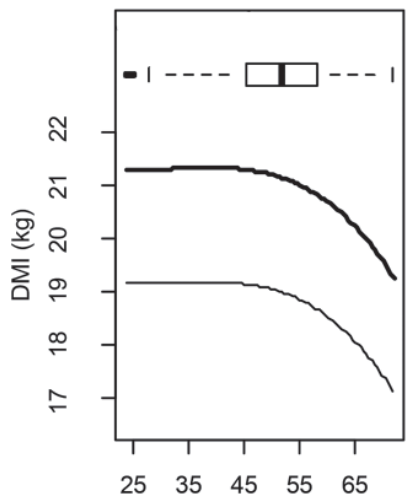

TH at 0900h

d

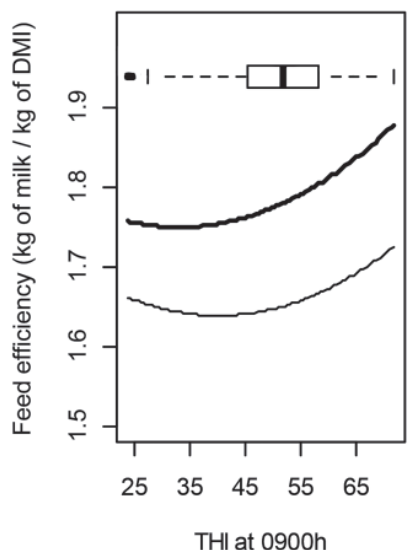

g

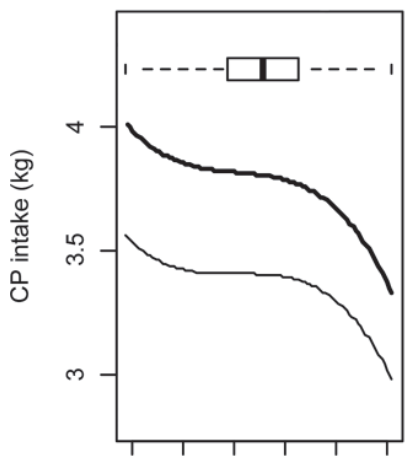

$\begin{array}{llllll}25 & 35 & 45 & 55 & 65 & 75\end{array}$

$\mathrm{THI}_{\text {adj }}$ at $0900 \mathrm{~h}$ b

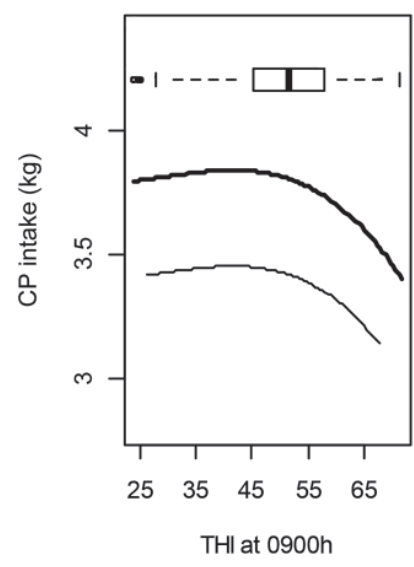

e

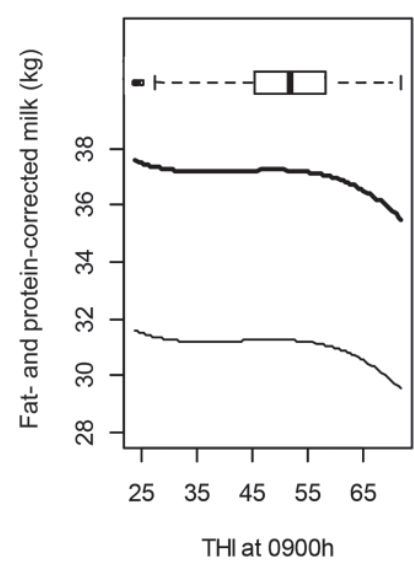

h

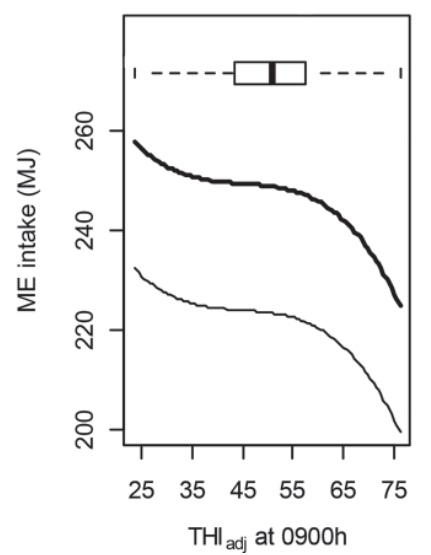

C
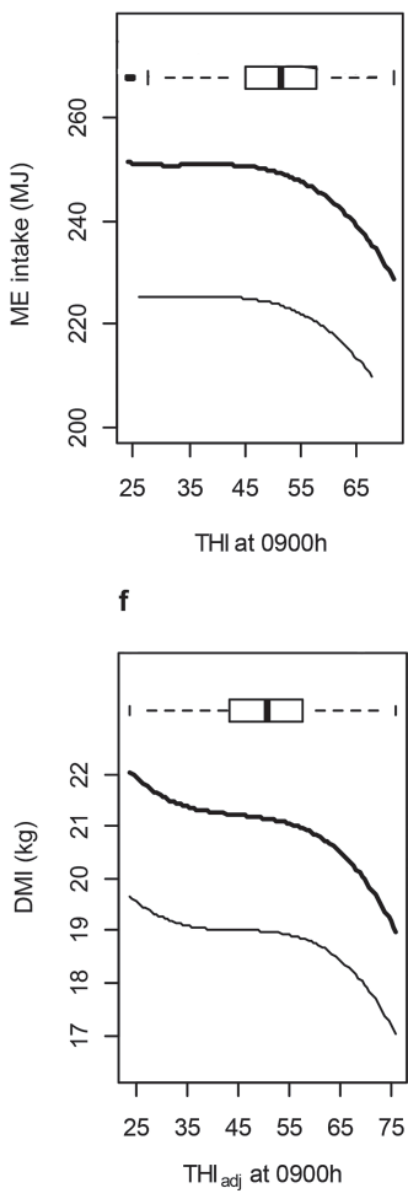

i

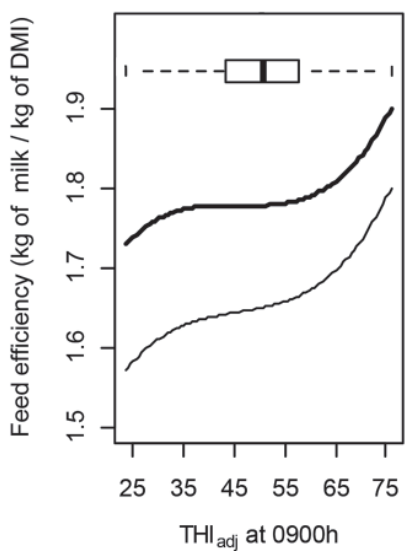

Figure 3. The effects of temperature-humidity index (THI; a-e) and temperature adjusted for humidity, wind speed, and solar radiation $\left(\mathrm{THI}_{\mathrm{adj}}\right.$; $\left.\mathrm{f}-\mathrm{i}\right)$ on daily DMI $(\mathrm{a}, \mathrm{f})$, daily CP intake $(\mathrm{b}, \mathrm{g})$, daily metabolizable energy intake $(\mathrm{c}, \mathrm{h})$, and feed efficiency (kg of fat- and proteincorrected milk yield/kg of DMI) (d, i), and (e) fat- and protein-corrected milk yield in 328 dairy cattle on a research farm in Scotland. Cows belonged to select (thick line) genetic merit or control (thin line) groups. Temperature and humidity were recorded at a single outdoor weather station $85 \mathrm{~m}$ from the cattle building. The median THI for the study period is represented by the thick line in the center of each boxplot, the left and right limits of the box are the 1st and 3rd quartiles of the data, respectively, and the whiskers show the range of the data minus values $>1.5$ times the interquartile range (open circles). Curves are adjusted for all significant terms in Equation [6], and statistical estimates for the effects presented here are provided in Table 5 and Supplemental Table S1 (https://doi.org/10.3168/jds.2016-11047) for THI and THI ${ }_{\text {adj }}$, respectively. Panels a-c and $\mathrm{f}-\mathrm{h}$ are based on 73,058 records, and $\mathrm{d}$ and $\mathrm{i}$ are based on 71,345 records. Models testing for the effects of THI (controlling for wind speed and sunshine) explained feed intake and feed efficiency better than models testing for the effects of $\mathrm{THI}_{\text {adj }}$. 


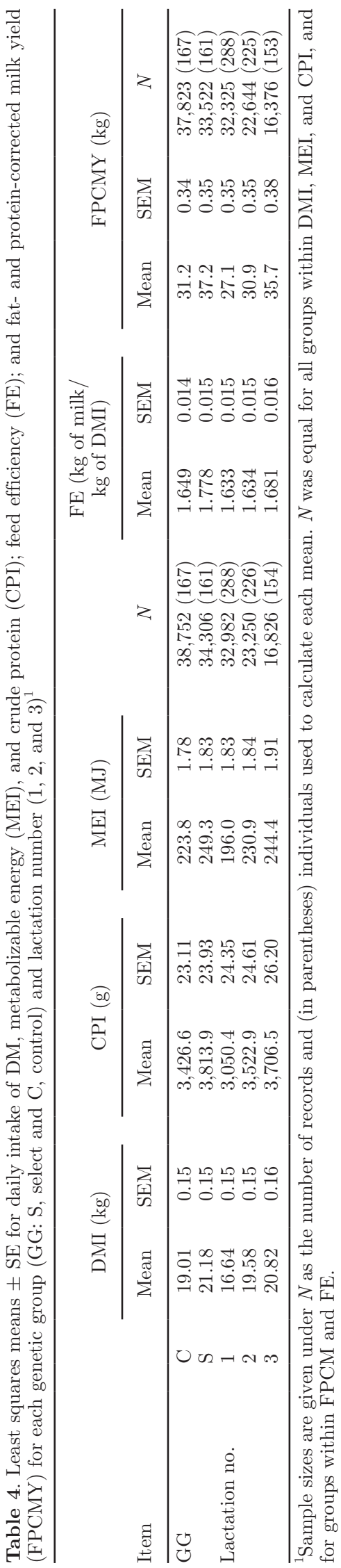

DMI decreased $11.5 \%$ in select cows and $12.8 \%$ in controls between 73.9 THI units (the highest THI recorded at $0900 \mathrm{~h}$ ) and 38.9 THI units. The FPCMY showed an overall decrease with increasing THI (Supplemental Table S1, Figure 3e). The THI did not affect the feed intake or FPCMY of select and control cows differently (Table 5, Supplemental Table S1, Figure 3a-c, e). The relationship between THI and FE, by contrast, varied with genetic merit: FE increased with increasing THI after 33.19 THI units in select cows, and after 40.17 THI units in control cows (Table 5, Figure 3d). Feed intake showed an overall increase with WS in cows of both genetic groups, and the rate of increase was greater in select than in control cows (Table 5, Supplemental Table S1, Figure 4a-c). The effects of WS on FE also varied with genetic group: FE in control cows decreased with increasing WS until WS reached $4.3 \mathrm{~m} / \mathrm{s}$ and then FE increased with increasing WS, whereas FE in select cows decreased until WS reached $5.6 \mathrm{~m} / \mathrm{s}$ (Table 5, Figure 4d). There was a trend toward a decrease in FPCMY with increasing WS, but the relationship was not statistically significant (Supplemental Table S1). The 3 feed intake traits decreased as nSun increased, whereas FE and FPCMY increased as nSun increased (Table 5, Supplemental Table S1, Figure 5a-e). The rate of decline in feed intake was steeper on days with fewer hours of sunshine (Figure $5 \mathrm{a}-\mathrm{c}$ ). Select cows decreased DMI and CPI with increasing sunshine hours at a greater rate than controls (Figure 5a,b), but nSun did not affect the 2 genetic groups differently for MEI or FE (Figure 5c,d).

\section{How Did Feeding Traits Vary with DIM, Live Weight, and Condition Score?}

Feed intake increased with DIM until d $123.1 \pm 0.16$ (mean across the 3 feed intake traits), then decreased and finally increased again on d $276.3 \pm 8.68$ (Table 5, Supplemental Table S1 and Figure S2; https://doi. org/10.3168/jds.2016-11047). Feed efficiency decreased with days in milk (Table 5, Supplemental Figure S2). Feed intake increased with increasing LW to a weight of $638.1 \pm 5.76 \mathrm{~kg}$ (mean across the 3 traits), and then decreased (Supplemental Figure S3a-c; https://doi. org/10.3168/jds.2016-11047). Feed efficiency decreased with increasing LW in cows lighter than $488.3 \mathrm{~kg}$, and then increased with LW until cows reached a weight of $706.4 \mathrm{~kg}$, before decreasing with increasing LW (Supplemental Figure S3d). The DMI, MEI, and FE increased with increasing CS until cows reached a score of $2.2 \pm 0.22$ units, before decreasing with increasing CS (Supplemental Figure S4; https://doi.org/10.3168/ jds.2016-11047). The CPI was not influenced by CS (Supplemental Table S1). 
Table 5. Linear mixed effects models to test the effect of weather [temperature-humidity index (THI), wind speed (WS), and hours of sunshine (nSun); means summarized over $3 \mathrm{~d}$ ] and genetic group (select or control) on DMI (73,058 records) and feed efficiency (71,345 records) in 328 Holstein Friesian cows during the years 2004-2011

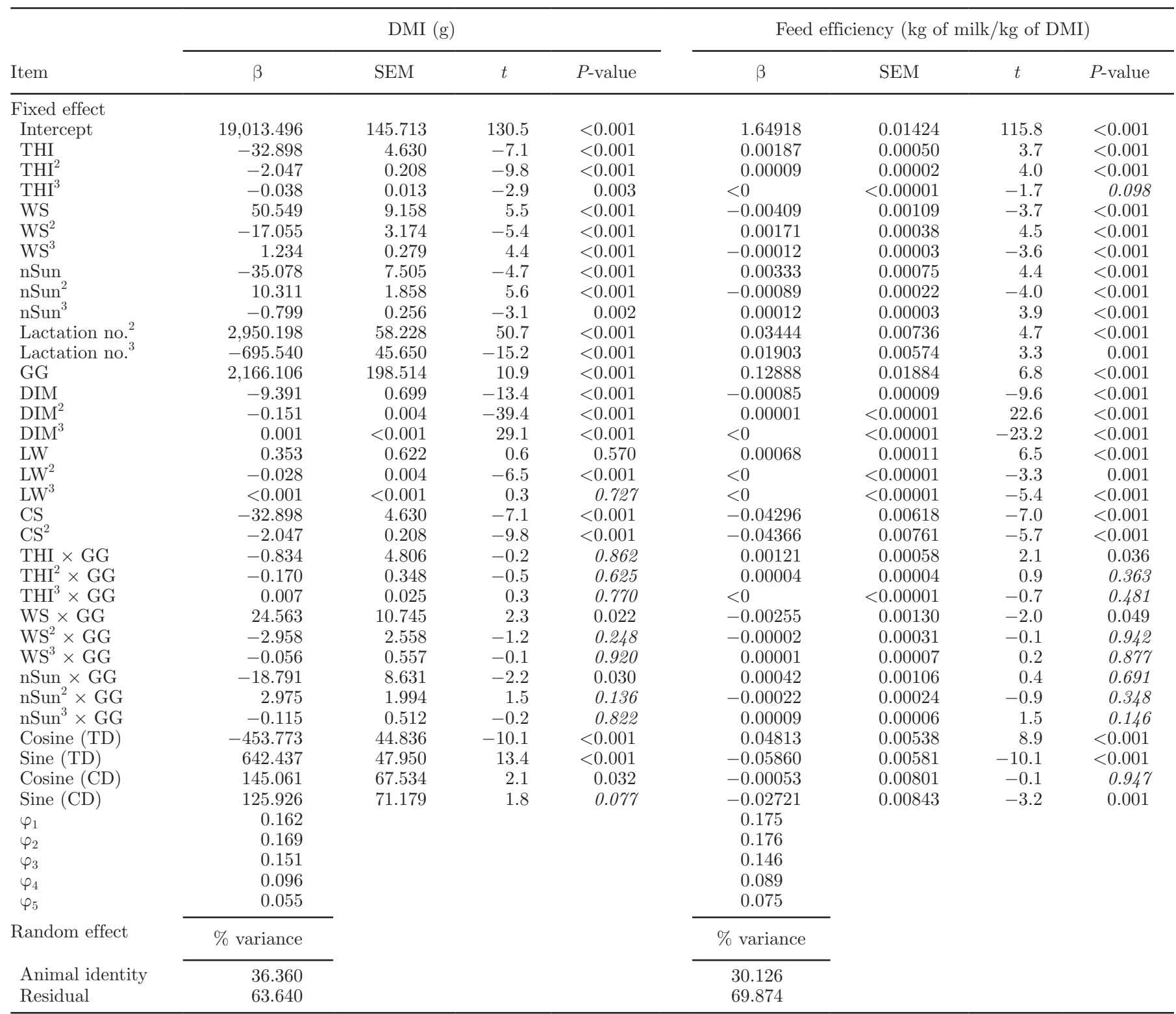

${ }^{1} \mathrm{TD}=$ running test day (the day of feeding); $\mathrm{CD}=$ running calving date; $\mathrm{GG}=$ genetic group; $\mathrm{LW}=$ live weight; $\mathrm{CS}=$ condition score; $\varphi_{\mathrm{n}}=$ the estimate of correlation at lag $\mathrm{n}$. Control was the reference (baseline) genetic group. Linear, quadratic ${ }^{(2)}$, and cubic $^{(3)}$ effects were tested for where indicated; lactation number is an ordered factor. Nonsignificant effects that were not components of significant interactions were removed from the final models; their $P$-values are italicized. Parameter estimates $(\beta)$ and SE marked $<0.001$ for DMI or $<0.00001$ for feed efficiency were positive values, and those marked $<0$ were between 0 and -0.001 for DMI or between 0 and -0.00001 for feed efficiency.

\section{How Did $\mathrm{THI}_{\text {adj }}$ Influence Feeding Traits in Cows of High and Average Genetic Merit?}

As $\mathrm{THI}_{\text {adj }}$ increased, feed intake decreased and FE increased (Supplemental Table S2, https://doi. org/10.3168/jds.2016-11047; Figure 3f-i). The rate of decrease with increasing $\mathrm{THI}_{\text {adj }}$ was greater in select than in control cows for DMI and CPI, but did not differ between genetic groups for MEI (Supplemental Table S2, Figure $3 \mathrm{f}-\mathrm{i}$ ). The slope of the relationship between $\mathrm{THI}_{\mathrm{adj}}$ and $\mathrm{FE}$ was steeper for control than select cows (Supplemental Table S2). 
a

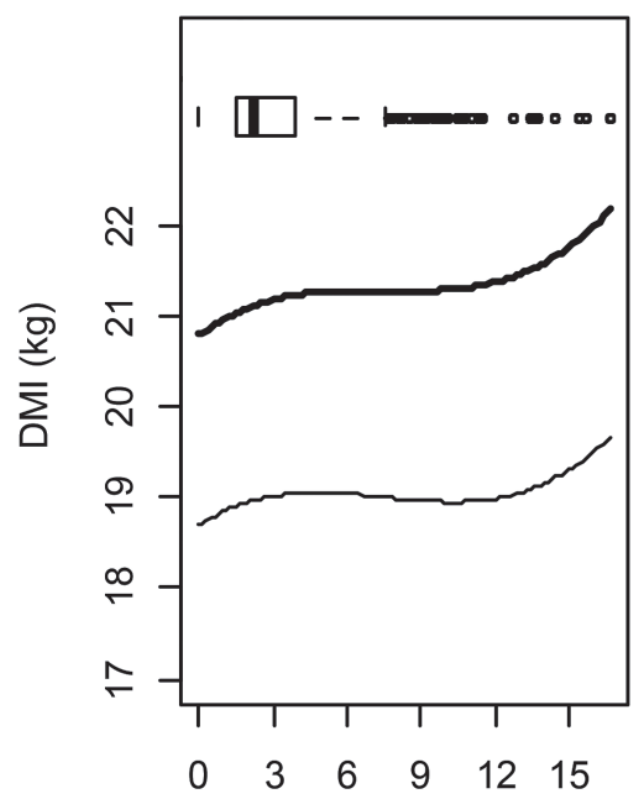

Wind speed at 0900h $(\mathrm{m} / \mathrm{s})$

C

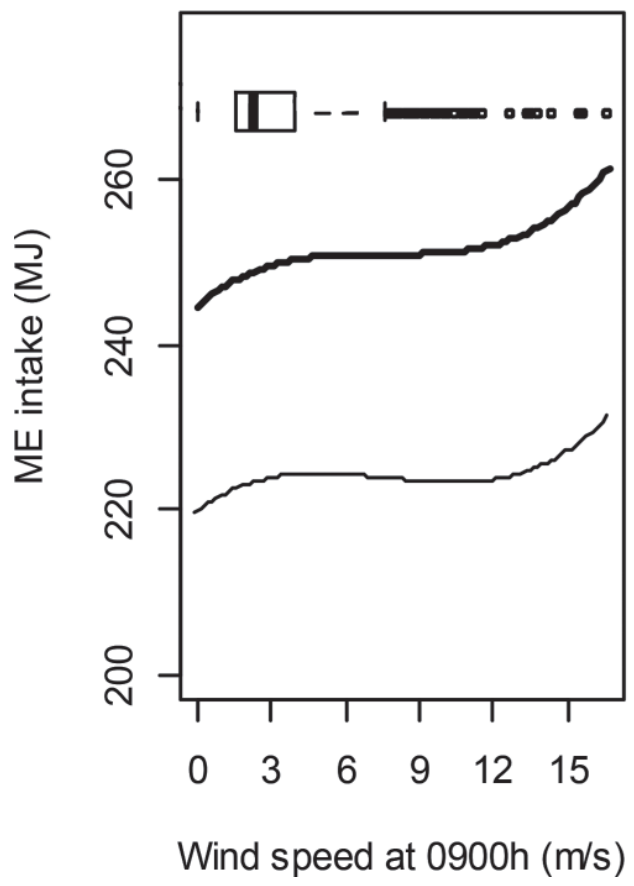

b

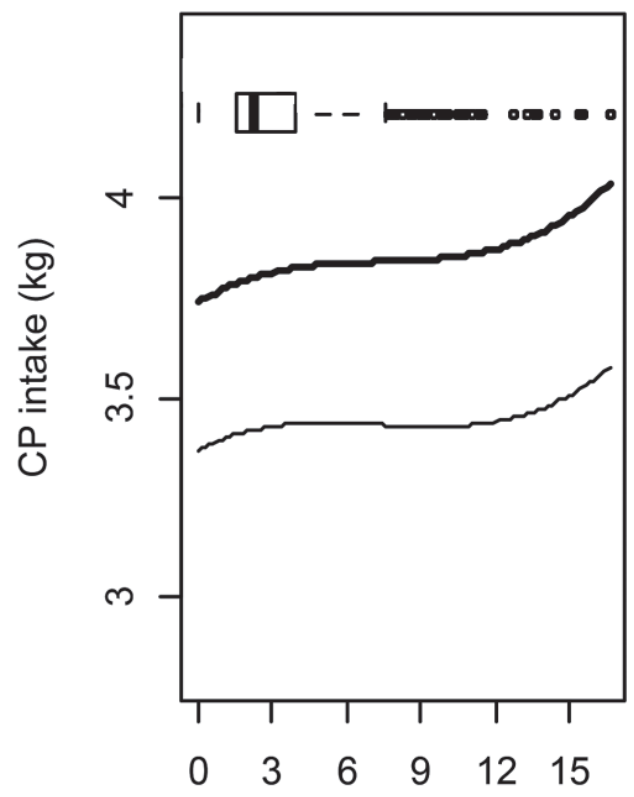

Wind speed at 0900h (m/s)

d

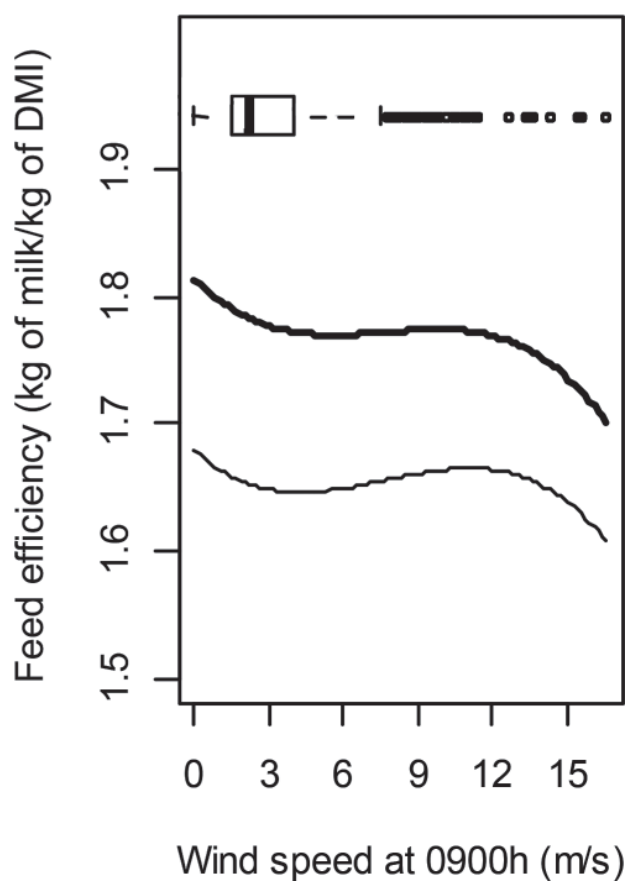

Figure 4. The effects of wind speed on (a) daily DMI, (b) daily CP intake, (c) daily ME intake, and (d) feed efficiency in a herd of dairy cattle depended on the cows' genetic line. Cows belonged to select (thick line) genetic merit or control (thin line) groups. Wind speed was recorded at a single outdoor weather station $85 \mathrm{~m}$ from the cattle building. All curves are adjusted for the terms in Equation [6], where significant, and statistical estimates for the effects presented here are provided in Table 5 and Supplemental Table S1 (https://doi.org/10.3168/jds.2016-11047). Wind speed did not have a statistically significant effect on fat- and protein-corrected milk yield (not shown). The median wind speed for the study period is represented by the thick line in the center of each boxplot, the left and right limits of each box are the 1st and 3rd quartiles of the data, respectively, and the whiskers show the range of the data minus values $>1.5$ times the interquartile range (open circles). 
a

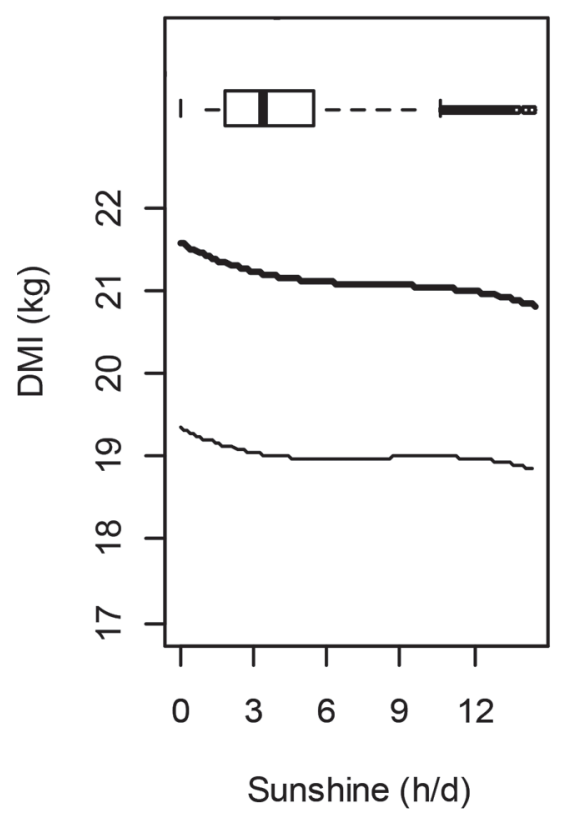

d

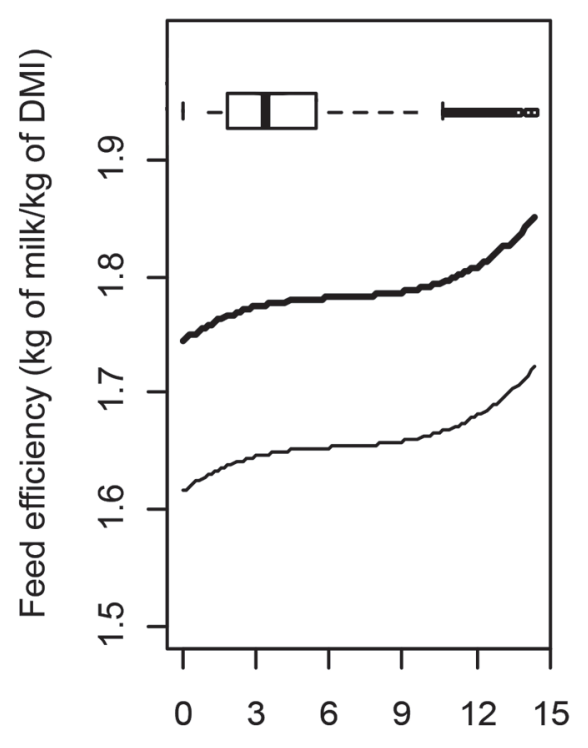

Sunshine $(h / d)$ b

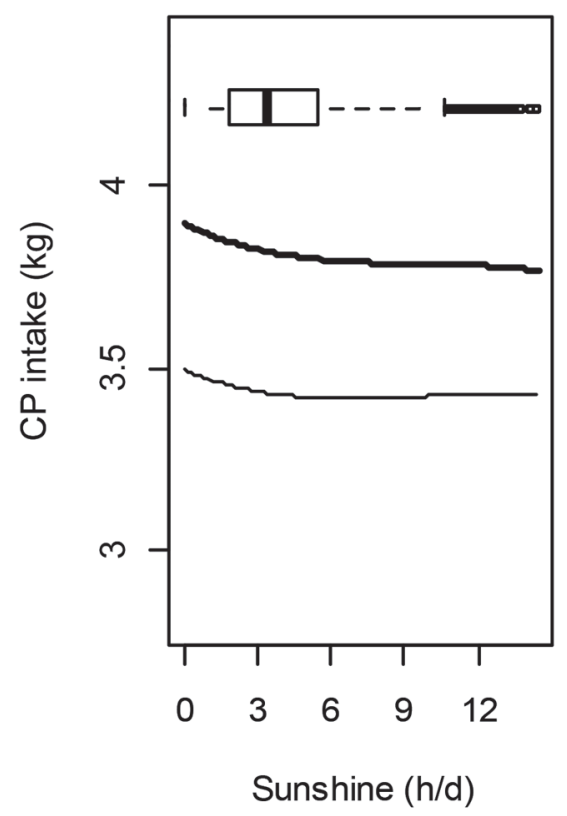

e

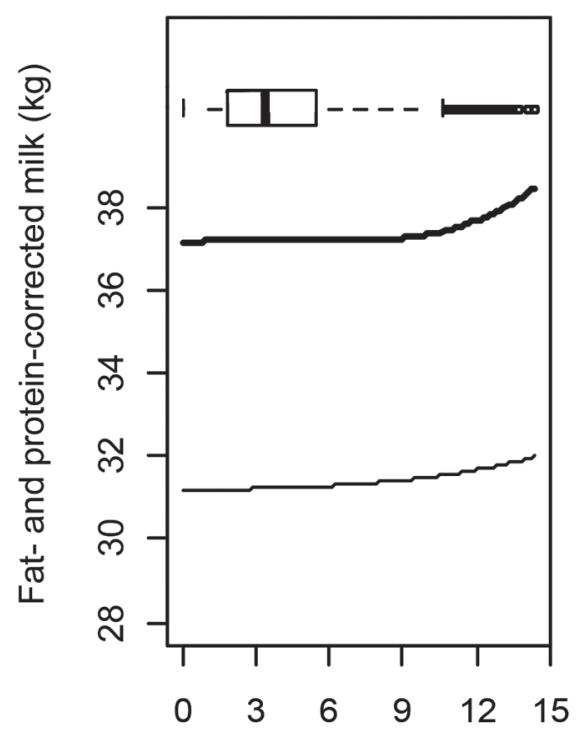

Sunshine (h/d)

Figure 5. The effects of sunshine on (a) daily DMI, (b) daily CP intake, (c) daily ME intake, (d) feed efficiency, and (e) fat- and proteincorrected milk yield in 328 dairy cows belonging to select (thick line) genetic merit or control (thin line) groups. The number of hours of sunshine per day was recorded at a single outdoor weather station at the farm. Curves are adjusted for all terms in Equation [6], where significant, and statistical estimates for the effects presented here are provided in Table 5 and Supplemental Table S1 (https://doi.org/10.3168/jds.2016-11047). Panels a-c are based on 73,058 records, and d-e are based on 71,345 records. The median number of hours of sunshine for the study period is represented by the thick line in the center of each boxplot, the left and right limits of each box are the 1st and 3rd quartiles of the data, respectively, and the whiskers show the range of the data minus values $>1.5$ times the interquartile range (open circles).' 


\section{How Did CCI Influence Feeding Traits in Cows of High and Average Genetic Merit?}

Feed intake increased with increasing CCI values when CCI was very low, and then decreased as CCI increased (Supplemental Table S3 and Figure S1a-c; https://doi.org/10.3168/jds.2016-11047). The relationship between feed intake and CCI was cubic for DMI and quadratic for CPI and MEI. Feed efficiency showed an overall increase with CCI (Supplemental Table S3), and select cows showed a steeper rate of increase in FE with CCI than control cows (Supplemental Figure S1d).

\section{DISCUSSION}

In dairy cows, increased $\mathrm{FE}$ is favorable from an economic perspective because a greater share of the energy in feed is converted into milk (Reynolds et al., 2011). It also minimizes the environmental impact of production because fewer resources are lost as manure, methane, and carbon dioxide per kilogram of milk produced (Arndt et al., 2015). The main aim of the present study was to determine how feed intake and FE vary in response to natural fluctuations in weather in housed cows in a temperate climate. Cows decreased feed intake (expressed as DMI, CPI, and MEI) and FPCMY, but became more efficient at converting DM to milk as THI increased. Feed intake increased with increasing WS, but decreased as the number of hours of sunshine increased. As cows received a TMR, which precluded the selection of different feed components, variation in CPI and MEI with weather arose largely from changes in DMI. Nevertheless, differences between the 3 feed intake traits in their responses to CCI and $\mathrm{THI}_{\text {adj }}$ suggest that weather can have subtle effects on the content or intake of $\mathrm{CP}$ and $\mathrm{ME}$ that are not fully explained by variation in DMI, perhaps due to differences in the density of components within the ration.

\section{How Well Did THI, $\mathrm{THI}_{\text {adj; }}$ and CCI Explain Feed Intake and Feed Efficiency?}

The CCI was developed as an indicator of the thermal comfort of cattle over a range of hot and cold conditions (Mader et al., 2010). Hammami et al. (2013) found that $\mathrm{THI}_{\mathrm{adj}}$ and CCI explained production traits and SCC more effectively than THI (Equation [2] in the present study). The $\mathrm{THI}_{\mathrm{adj}}$ and CCI take into account WS and solar radiation but THI does not. Here, we fitted a model containing not only THI but also WS and nSun as individual main effects, and compared its performance to alternative models containing $\mathrm{THI}_{\text {adj }}$ and
CCI. Our former model was better at explaining feed intake and $\mathrm{FE}$ than models containing $\mathrm{THI}_{\text {adj }}$ or CCI. This is probably because individual weather variables capture the complex ambient conditions experienced by the animal more comprehensively than single metrics, which are constrained by weightings that might be more appropriate under some conditions than others. For example, distinct thermal indices differ between climatic regions in their effectiveness as proxies of the environmental conditions associated with heat stress (Bohmanova et al., 2007). The superior performance of individual weather variables compared with metrics that condense the same variables into a single value suggests that a model containing main effects of $\mathrm{T}_{\mathrm{db}}$, $\mathrm{RH}$, WS, and nSun would perform better than one containing THI, WS, and nSun. Consistent with this idea, Dikmen and Hansen (2009) found that a model that fitted both $\mathrm{T}_{\mathrm{db}}$ and $\mathrm{RH}$ as main effects explained rectal temperature in lactating dairy cows as well or better than models containing 1 of 8 THI. Although models including individual weather variables appear to describe feed and production traits more closely, thermal indices are valuable because they condense complex ambient conditions into a single value that can be easily compared between studies or commercial settings. All 3 indices were similar in the shape of their relationships with the 4 feeding traits, except at their lower extremes. Interestingly, at low index values, $\mathrm{THI}_{\text {adj }}$ and CCI followed different directions in their relationships with 2 feed intake traits. This could reflect the apparently greater suitability of CCI compared with $\mathrm{THI}_{\text {adj }}$ for explaining feed intake at cooler temperatures. The CCI models were better at explaining DMI, CPI, and FE than THI $_{\text {adj }}$ models, which offers statistical support for this possibility.

\section{Comparing Timescales for Quantifying Weather Metrics}

Moving mean weather measurements spanning $3 \mathrm{~d}$ before and including feeding (i.e., means of weather across the TD, TD minus 1, and TD minus 2) usually explained feed intake and FE better than TD or 7-d means. This is consistent with Bertocchi et al. (2014), who reported that the THI recorded $2 \mathrm{~d}$ before the TD explained milk quality better than measurements taken $1,3,4$, or $5 \mathrm{~d}$ before the TD in Holsteins in northern Italy. Similarly, West et al. (2003) found that mean THI recorded $3 \mathrm{~d}$ before the TD explained DMI in Holsteins in southern Georgia better than THI recorded on the TD, or 1 or $2 \mathrm{~d}$ before the TD (although a $2-\mathrm{d}$ lag of mean $T_{d b}$ performed best overall). These lags reflect the time an animal spends consuming, digesting, and 
metabolizing feed (West et al., 2003). We also propose that expressing lags as moving means allows short-lived periods of harsh weather to be captured in the analysis.

\section{Feed Intake Decreased and Feed Efficiency Increased with Increasing THI}

Our observation that feed intake decreased with increasing THI supports work on DMI in dairy cows (Bouraoui et al., 2002; West, 2003; Gorniak et al., 2014), on DMI in cattle steers (Kang et al., 2016) and on DMI and MEI in sheep (Dixon et al., 1999). Decreases in DMI under conditions of heat stress are associated with decreases in daily and resting metabolic heat production, longer digestion times, and a shift from fat to glucose utilization in dairy cows (Eslamizad et al., 2015). In southern Georgia (United States), DMI decreased $0.51 \mathrm{~kg}$ for every 1 unit increase in test day THI between approximately 73 and 82 THI units (West et al., 2003). Ominski et al. (2002) reported a 6.5\% decline in DMI during $5 \mathrm{~d}$ of experimental exposure to heat stress (mean daily THI $\sim 73.5$ ) compared with control conditions (THI $\sim 68.8$ ) in lactating Holsteins in Manitoba, Canada. We observed lower declines (3.8 and $4.3 \%$ in select and control cows, respectively) than Ominski et al. (2002) for the same THI values, perhaps owing to a shorter duration of exposure in our study. Severe heat stress can bring about declines in cow DMI as high as 55\% compared with thermoneutral conditions (NRC, 1981). By contrast, at the highest THI recorded in our study, DMI decreased by 11.5 and $12.8 \%$ (select and control cows, respectively) compared with peak intake. Under the environmental conditions and feeding regimen experienced in our study, cows received the nutrients and energy necessary to support their productive functions (NRC, 2001). Nevertheless, predicted increases in temperature (IPCC, 2013) combined with increased maintenance requirements as a consequence of heat stress (reviewed in Baumgard and Rhoads, 2012) mean that producers should stay alert to cows' energetic and nutritional requirements, falling below these levels even in temperate regions.

We had expected the effect of THI on feed intake to be greater in cows of high than average genetic merit. Contrary to our prediction, however, the slopes did not differ between the 2 groups. At least 3 reasons, which are not mutually exclusive, are possible. (1) Cows may not have experienced warm enough temperatures for a difference to be detected (i.e., for heat stress to occur and affect feed intakes). However, feed intake varied with THI within genetic groups, so cows were clearly affected by the range of temperatures in the study. (2) The THI alone may not have fully captured the re- sponse of cows to weather. The observation that THI, $\mathrm{THI}_{\text {adj }}$, CCI, WS, and nSun affected high genetic merit cows differently from controls with respect to some of the feed intake traits is consistent with this possibility.

(3) Select cows might have modified other aspects of feeding to maintain the same overall DMI. This might involve feeding at a cooler time of day (Adin et al., 2008) or adjusting meal characteristics (D. L. Hill and E. Wall, unpublished data). Such questions can be addressed using individual animal feed intake recording systems, such as that used in the present study, which provide detailed information on intake, duration, and timing of individual visits.

Our measurements of FE agree with those carried out by other authors under similar environmental conditions [e.g., Su et al. (2013) recorded $1.66 \pm 0.02$ $\mathrm{kg}$ of FCM per $\mathrm{kg}$ of DMI at 50.6 THI units at 0900 h]. Although both FPCMY and DMI declined with increasing THI in our study, the concurrent increase in $\mathrm{FE}$ indicates that the decline in milk yield was less than the decline in DMI at a given THI. Our findings cannot be attributed to changes in CS, body mass, stage of lactation or lactation number, which affect FE through changes in energy balance and maintenance requirements (Reynolds et al., 2011), because these were controlled for statistically in our analyses. The increase in FE with increasing THI supports work carried out by Kang et al. (2016) under similar environmental conditions. Kang et al. (2016) found that FE in housed steers increased from March (mean THI 49 units) to the warmer month of April (56 THI units). Studies carried out in warmer regions, however, have reported lower FE under hot (high $24 \mathrm{~h}$ ambient temperature $>21^{\circ} \mathrm{C}$ in Britt et al., 2003; mean daily THI 76.5 in $\mathrm{Su}$ et al., 2013) than mild ( $\leq 21^{\circ} \mathrm{C}$; THI 53$)$ conditions (Britt et al., 2003; Su et al., 2013). In contrast to our findings, the difference in $\mathrm{FE}$ was driven by THI having more pronounced effects on milk yield than on DMI under warmer conditions in these studies (Britt et al., 2003). Taken together, these results support previous suggestions that FE increases with mild heat stress but rapidly decreases when heat stress becomes more severe (Yunianto et al., 1997; Baumgard and Rhoads, 2012). This may reflect the increased energetic cost of evaporative cooling under severe compared with mild heat stress (Yunianto et al., 1997).

\section{Feed Intake Increased with Increasing Wind Speed}

Cows in our study were exposed to natural ventilation from windows, open areas, and slits between timber panels, but were sheltered from strong winds. Moderate WS can alleviate the effects of high ambi- 
ent temperatures on rectal temperature (Dikmen and Hansen, 2009) and productivity (Hill and Wall, 2015) in dairy cows. We found that FE decreased with increasing WS, presumably because cows increased feed intake but not milk yield as WS increased. The rate of increase in feed intake with increasing WS was greater in select than in control cows because higher yielding cows have a greater heat increment to offload.

\section{Feed Intake Decreased and Feed Efficiency Increased as Sunshine Hours Increased}

The number of hours of sunshine is presumably a function of both solar radiation, which could reach cows directly through the open areas in the building or indirectly from the roof, and photoperiod. Other studies have observed a positive relationship between milk production and day length, perhaps because of a decline in melatonin production with increasing photoperiod (Dahl et al., 2000). Although we accounted for seasonality in our study, it is possible that endocrine mechanisms stimulated by residual changes in photoperiod explain the positive influence of sunshine on FPCMY and FE. Holstein heifers experimentally subjected to photoperiods of $16 \mathrm{~h}$ of light: $8 \mathrm{~h}$ of darkness converted feed into body mass more efficiently than heifers that experienced $8 \mathrm{~h}$ of light:16 h of darkness irrespective of whether they received ad libitum or restricted feed (Petitclerc et al., 1983). In contrast to our results, Swedish red and white bulls on an ad libitum concentrate diet and Holstein heifers fed concentrates and forage ad libitum increased DMI as day length increased (Petitclerc et al., 1983; Mossberg and Jönsson, 1996). The findings of Mossberg and Jönsson (1996) and Petitclerc et al. (1983) and our adjustments for seasonality suggest that the declines in DMI with increasing sunshine in the present study are more likely to be a consequence of increased solar radiation on the animals rather than photoperiod. Interestingly, the effects of sunshine differed between the 2 genetic lines in our study: select cows decreased DMI and CPI with increasing sunshine hours at a greater rate than controls.

\section{Implications for Climate Change}

We observed decreases in feed intake and FPCMY with increasing THI under conditions currently experienced in a temperate region, suggesting that temperate herds may be more sensitive to ambient heat than is currently recognized. Dunn et al. (2014) predicted a steady increase in the number of days on which THI exceeds 70 units in the United Kingdom over the 21st century. In southeast England, the number of days over
70 THI units was predicted to exceed $40 \mathrm{~d} / \mathrm{yr}$ by 2100 (Dunn et al., 2014). Although these predicted conditions are milder than those currently experienced in many regions that rely on dairy farming, the low tolerance of temperate zone animals to high THI is cause for concern. Nevertheless, our finding that FE increased with increasing THI suggests that some of the future costs of lost productivity may be offset by reduced economic expenditure on feed per kilogram of milk, at least under conditions of mild heat stress.

Temperatures inside cattle sheds are 3 to $6^{\circ} \mathrm{C}$ warmer than outdoors in northern Europe (Seedorf et al., 1998), and up to $3.5^{\circ} \mathrm{C}$ warmer or 6 THI units higher indoors than outdoors in central Europe (Erbez and Chládek, 2010). In our study, the feed face was just $1.23^{\circ} \mathrm{C}$ warmer than outside and humidity inside the building did not differ from values measured outdoors during the months for which indoor data were available (late April to early July). The responses to temperature and humidity that we describe are therefore likely to reflect those in a grazing system (though potential interactions with feed type, and physical activity and other behaviors between housed and grazing animals should be considered). It is worth noting that stocking density was higher between November and March than the other months of our study because cows from a separate study were housed with our study subjects for the winter. Body heat from the additional animals may have therefore helped to buffer our subjects from the cold. For animals grazing on warm days, WS is expected to have a more pronounced effect in alleviating heat load than we observed in our housed cows.

\section{CONCLUSIONS}

This is, to our knowledge, the first longitudinal study of the effects of weather on FE in dairy cows. Our first objective was to compare how well 3 thermal indices described feed intake and FE. Models considering THI, WS, and sunshine were more effective at explaining cows' responses to temperate weather conditions than models containing single metrics $\left(\mathrm{THI}_{\text {adj }}\right.$ or $\left.\mathrm{CCI}\right)$. Next, we showed that moving mean weather measurements spanning the TD and the 2 preceding days ( $3 \mathrm{~d}$ means) explained feeding traits better than TD or $7 \mathrm{~d}$ means, which probably reflects the duration of digestive processes. Finally, we found that milk yield, feed intake, and $\mathrm{FE}$ are influenced by current weather conditions in a temperate climate. As THI and CCI increased, feed intake decreased, as predicted, but the efficiency of converting DM to milk increased. Interestingly, high genetic merit and control cows differed in their responses to weather, which suggests that they differ 
in their sensitivities to weather or their coping tactics. Understanding how weather influences feed intake and efficiency can help shape management and selective breeding strategies, and will become an important aspect of resilience to future climate change. Heritable genetic variation exists for $\mathrm{FE}$, and so using feed intake records to identify cows that maintain efficiency under different weather conditions provides opportunities to breed for improved resilience to weather-related stress.

\section{ACKNOWLEDGMENTS}

Scotland's Rural College (SRUC) receives grant-inaid from the Scottish government. This work was funded by the Scottish Government Rural Affairs and the Environment Portfolio Strategic Research Programme 2011 to 2016 (Environmental Change Programme and the Climate Change Centre of Expertise, ClimateXChange). We are grateful to farm staff and data managers at the SRUC Dairy Research Centre, especially Ainsley Bagnall, David Bell, and Ian Archibald, for collecting and maintaining such excellent records. We thank Marie Haskell for making the indoor microclimate data available to us, and 2 anonymous referees for helping to improve the manuscript.

\section{REFERENCES}

Adin, G., R. Solomon, E. Shoshani, I. Flamenbaum, M. Nikbachat, E. Yosef, A. Zenou, I. Halachmi, A. Shamay, A. Brosh, S. Mabjeesh, and J. Miron. 2008. Heat production, eating behavior and milk yield of lactating cows fed two rations differing in roughage content and digestibility under heat load conditions. Livest. Sci. 119:145-153.

Ångstrom, A. 1924. Solar and terrestrial radiation. Q. J. R. Meteorol. Soc. 50:121-125.

Arndt, C., J. M. Powell, M. J. Aguerre, P. M. Crump, and M. A. Wattiaux. 2015. Feed conversion efficiency in dairy cows: Repeatability, variation in digestion and metabolism of energy and nitrogen, and ruminal methanogens. J. Dairy Sci. 98:3938-3950.

Association of Official Analytical Chemists. 1990. Official Methods of Analysis. 15th ed. AOAC, Arlington, VA.

Basarab, J. A., M. A. Price, J. L. Aalhus, E. K. Okine, W. M. Snelling, and K. L. Lyle. 2003. Residual feed intake and body composition in young growing cattle. Can. J. Anim. Sci. 83:189-204.

Bauman, D. E., and W. B. Currie. 1980. Partitioning of nutrients during pregnancy and lactation: A review of mechanisms involving homeostasis and homeorhesis. J. Dairy Sci. 63:1514-1529.

Baumgard, L. H., and R. P. Rhoads. 2012. Ruminant production and metabolic responses to heat stress. J. Anim. Sci. 90:1855-1865.

Bell, M., E. Wall, G. Russell, G. Simm, and A. Stott. 2011. The effect of improving cow productivity, fertility, and longevity on the global warming potential of dairy systems. J. Dairy Sci. 94:3662-3678.

Berman, A. 2005. Estimates of heat stress relief needs for Holstein dairy cows. J. Anim. Sci. 83:1377-1384.

Bernabucci, U., N. Lacetera, L. H. Baumgard, R. P. Rhoads, B. Ronchi, and A. Nardone. 2010. Metabolic and hormonal acclimation to heat stress in domesticated ruminants. Animal 4:1167-1183.

Berry, D. P., and J. J. Crowley. 2013. Cell Biology Symposium: Genetics of feed efficiency in dairy and beef cattle. J. Anim. Sci. 91:1594-1613.
Bertocchi, L., A. Vitali, N. Lacetera, A. Nardone, G. Varisco, and U. Bernabucci. 2014. Seasonal variations in the composition of Holstein cow's milk and temperature humidity index relationship. Animal 8:667-674.

Blaxter, K. L. 1962. The Energy Metabolism of Ruminants. Hutchinson's Scientific and Technical Publications, London, UK.

Bohmanova, J., I. Misztal, and J. Cole. 2007. Temperature-humidity indices as indicators of milk production losses due to heat stress. J. Dairy Sci. 90:1947-1956.

Bojanowski, J. S. 2013. sirad: Functions for calculating daily solar radiation and evapotranspiration. Version 2.2.2. Accessed Dec. 16, 2014. https://cran.r-project.org/web/packages/sirad/index.html.

Bouraoui, R., M. Lahmar, A. Majdoub, M. Djemali, and R. Belyea. 2002. The relationship of temperature-humidity index with milk production of dairy cows in a Mediterranean climate. Anim. Res. 51:479-491.

Britt, J. S., R. C. Thomas, N. C. Speer, and M. B. Hall. 2003. Efficiency of converting nutrient dry matter to milk in Holstein herds. J. Dairy Sci. 86:3796-3801.

Burnham, K. P., and D. R. Anderson. 2002. Information and Likelihood Theory: A Basis for Model Selection and Inference. In Model Selection and Multimodel Inference: A Practical InformationTheoretic Approach. K. P. Burnham and D. R. Anderson, ed. Springer-Verlag, New York, NY.

Burnham, K. P., D. R. Anderson, and K. P. Huyvaert. 2011. AIC model selection and multimodel inference in behavioral ecology: Some background, observations, and comparisons. Behav. Ecol. Sociobiol. 65:23-35.

Coppock, C. E., P. A. Grant, S. J. Portzer, D. A. Charles, and A. Escobosa. 1982. Lactating dairy-cow responses to dietary-sodium, chloride, and bicarbonate during hot weather. J. Dairy Sci. $65: 566-576$

Dahl, G. E., B. A. Buchanan, and H. A. Tucker. 2000. Photoperiodic effects on dairy cattle: A review. J. Dairy Sci. 83:885-893.

DiGiacomo, K., L. Marett, W. Wales, B. Hayes, F. Dunshea, and B. Leury. 2014. Thermoregulatory differences in lactating dairy cattle classed as efficient or inefficient based on residual feed intake. Anim. Prod. Sci. 54:1877-1881.

Dikmen, S., and P. Hansen. 2009. Is the temperature-humidity index the best indicator of heat stress in lactating dairy cows in a subtropical environment? J. Dairy Sci. 92:109-116.

Dixon, R. M., R. Thomas, and J. H. G. Holmes. 1999. Interactions between heat stress and nutrition in sheep fed roughage diets. J. Agric. Sci. 132:351-359.

Dunn, R. J., N. E. Mead, K. M. Willett, and D. E. Parker. 2014. Analysis of heat stress in UK dairy cattle and impact on milk yields. Environ. Res. Lett. 9:064006.

Erbez, D. F., and G. Chládek. 2010. The relationship between temperature and humidity outside and inside the permanently opensided cows' barn. Acta Universitatis Agriculturae et Siliviculturae Mendelianae Brunensis Brno, Èeská Republika LVIII:91-96.

Eslamizad, M., O. Lamp, M. Derno, and B. Kuhla. 2015. The control of short-term feed intake by metabolic oxidation in late-pregnant and early lactating dairy cows exposed to high ambient temperatures. Physiol. Behav. 145:64-70.

Gorniak, T., U. Meyer, K.-H. Südekum, and S. Dänicke. 2014. Impact of mild heat stress on dry matter intake, milk yield and milk composition in mid-lactation Holstein dairy cows in a temperate climate. Arch. Anim. Nutr. 68:358-369.

Graunke, K. L., T. Schuster, and L. M. Lidfors. 2011. Influence of weather on the behaviour of outdoor-wintered beef cattle in Scandinavia. Livest. Sci. 136:247-255.

Hammami, H., J. Bormann, N. M'hamdi, H. Montaldo, and N. Gengler. 2013. Evaluation of heat stress effects on production traits and somatic cell score of Holsteins in a temperate environment. J. Dairy Sci. 96:1844-1855.

Haskell, M. J., K. Masłowska, D. J. Bell, D. J. Roberts, and F. M. Langford. 2013. The effect of a view to the surroundings and microclimate variables on use of a loafing area in housed dairy cattle. Appl. Anim. Behav. Sci. 147:28-33. 
Herd, R. M., and P. F. Arthur. 2009. Physiological basis for residual feed intake. J. Anim. Sci. 87(E. Suppl.):E64-E71.

Hill, D., and E. Wall. 2015. Dairy cattle in a temperate climate: The effects of weather on milk yield and composition depend on management. Animal 9:138-149.

IPCC. 2013. Climate Change 2013: The Physical Science Basis. Contribution of Working Group I to the Fifth Assessment Report of the Intergovernmental Panel on Climate Change. T. F. Stocker, D. Qin, G.-K. Plattner, M. Tignor, S. K. Allen, J. Boschung, A Nauels, Y. Xia, V. Bex, and P. M. Midgley, ed. Cambridge University Press, Cambridge, UK and New York, NY.

Jenkins, G. J., J. M. Murphy, D. M. H. Sexton, J. A. Lowe, P. Jones, and C. G. Kilsby. 2009. UK Climate Projections: Briefing report. Met Office Hadley Centre, Exeter, UK.

Kadzere, C. T., M. R. Murphy, N. Silanikove, and E. Maltz. 2002. Heat stress in lactating dairy cows: A review. Livest. Prod. Sci. 77:59-91

Kang, H. J., I. K. Lee, M. Y. Piao, M. J. Gu, C. H. Yun, H. J. Kim, K. H. Kim, and M. Baik. 2016. Effects of ambient temperature on growth performance, blood metabolites, and immune cell populations in Korean cattle steers. Asian-australas. J. Anim. Sci 29:436-443.

Lowman, B. G., N. Scott, and S. Somerville. 1976. Condition Scoring of Cattle. Bulletin No. 6. East of Scotland College of Agriculture, Edinburgh, UK.

Mader, T., L. Johnson, and J. Gaughan. 2010. A comprehensive index for assessing environmental stress in animals. J. Anim. Sci. 88:2153-2165.

Mader, T. L., M. S. Davis, and T. Brown-Brandl. 2006. Environmental factors influencing heat stress in feedlot cattle. J. Anim. Sci. 84:712-719.

Manzanilla Pech, C. I., R. Veerkamp, M. Calus, R. Zom, A. van Knegsel, J. Pryce, and Y. De Haas. 2014. Genetic parameters across lactation for feed intake, fat-and protein-corrected milk, and liveweight in first-parity Holstein cattle. J. Dairy Sci. 97:5851-5862.

Martello, L. S., S. da Luz e Silva, R. da Costa Gomes, R. R. da Silva Corte, and P. R. Leme. 2016. Infrared thermography as a tool to evaluate body surface temperature and its relationship with feed efficiency in Bos indicus cattle in tropical conditions. Int. J. Biometeorol. 60:173-181.

Mossberg, I., and H. Jönsson. 1996. The influence of day length and temperature on food intake and growth rate of bulls given concentrate or grass silage ad libitum in two housing systems. Anim. Sci. 62:233-240.

NRC. 1971. A guide to environmental research on animals. Natl. Acad. Sci., Washington, DC.

NRC. 1981. Effect of Environment on Nutrient Requirements of Domestic Animals. Natl. Acad. Press, Washington, DC.

NRC. 2001. Nutrient Requirements of Dairy Cattle. 7th rev. ed. Natl. Acad. Press, Washington, DC.

Nkrumah, J. D., E. K. Okine, G. W. Mathison, K. Schmid, C. Li, J. A. Basarab, M. A. Price, Z. Wang, and S. S. Moore. 2006. Relationships of feedlot feed efficiency, performance, and feeding behavior with metabolic rate, methane production, and energy partitioning in beef cattle. J. Anim. Sci. 84:145-153.

Ominski, K. H., A. D. Kennedy, K. M. Wittenberg, and S. A. M. Nia. 2002. Physiological and production responses to feeding schedule in lactating dairy cows exposed to short-term, moderate heat stress. J. Dairy Sci. 85:730-737.

Petitclerc, D., L. T. Chapin, R. S. Emery, and H. A. Tucker. 1983. Body growth, growth-hormone, prolactin and puberty response to photoperiod and plane of nutrition in Holstein heifers. J. Anim. Sci. 57:892-898.

Pinheiro, J., and D. Bates. 2014. Package 'nlme': Linear and Nonlinear Mixed Effects Models. Version 3.1-121. Accessed Jul. 1, 2015. https://cran.r-project.org/web/packages/nlme/index.html.

Prescott, J. A. 1940. Evaporation from a water surface in relation to solar radiation. Trans. R. Soc. S. Aust. 64:114-125.

R Core Team. 2014. R: A language and environment for statistical computing. R Foundation for Statistical Computing, Vienna, Austria.

Renaudeau, D., A. Collin, S. Yahav, V. de Basilio, J. Gourdine, and R. Collier. 2012. Adaptation to hot climate and strategies to alleviate heat stress in livestock production. Animal 6:707-728.

Reynolds, C. K., L. A. Crompton, and J. A. N. Mills. 2011. Improving the efficiency of energy utilisation in cattle. Anim. Prod. Sci. 51:6-12.

Rhoads, M., R. Rhoads, M. VanBaale, R. Collier, S. Sanders, W. Weber, B. Crooker, and L. Baumgard. 2009. Effects of heat stress and plane of nutrition on lactating Holstein cows: I. Production, metabolism, and aspects of circulating somatotropin. J. Dairy Sci. 92:1986-1997.

Seedorf, J., J. Hartung, M. Schroder, K. H. Linkert, S. Pedersen, H. Takai, J. O. Johnsen, J. H. M. Metz, P. W. G. G. Koerkamp, G. H. Uenk, V. R. Phillips, M. R. Holden, R. W. Sneath, J. L. Short, R. P. White, and C. M. Wathes. 1998. Temperature and moisture conditions in livestock buildings in Northern Europe. J. Agric. Eng. Res. 70:49-57.

Stamer, E., W. Junge, and E. Kalm. 1997. Temporal pattern of feeding behaviour of dairy cows kept in groups. Arch. Tierzucht 40:195214.

Su, H., Y. Wang, Q. Zhang, F. Wang, Z. Cao, M. A. U. Rahman, B. Cao, and S. Li. 2013. Responses of energy balance, physiology, and production for transition dairy cows fed with a low-energy prepartum diet during hot season. Trop. Anim. Health Prod. 45:1495-1503.

Thomas, P. C. S. Robertson, D. G. Chamberlain, R. M. Livingstone, P. H. Garthwaite, P. J. S. Dewey, R. Smart, and C. Whyte. 1988 Predicting the metabolizable energy (ME) content of compound feeds for ruminants. Pages 127-146 in Recent Advances in Animal Nutrition. W. Haresign and D. J. A. Cole, ed. Butterworths, London, UK.

UK Meteorological Office. 2012. Met Office Integrated Data Archive System (MIDAS) Land and Marine Surface Stations Data (1853-present), NCAS British Atmospheric Data Centre. Accessed November 6, 2012. http://badc.nerc.ac.uk/view/badc.nerc. ac.uk_ATOM_dataent_ukmo-midas.

Van Iaer, E., C. P. H. Moons, B. Sonck, and F. A. M. Tuyttens. 2014. Importance of outdoor shelter for cattle in temperate climates. Livest. Sci. 159:87-101.

West, J. W. 2003. Effects of heat-stress on production in dairy cattle. J. Dairy Sci. 86:2131-2144.

West, J. W., B. G. Mullinix, and J. K. Bernard. 2003. Effects of hot, humid weather on milk temperature, dry matter intake, and milk yield of lactating dairy cows. J. Dairy Sci. 86:232-242.

Yunianto, V. D., K. Hayashi, S. Kaneda, A. Ohtsuka, and Y. Tomita. 1997. Effect of environmental temperature on muscle protein turnover and heat production in tube-fed broiler chickens. Br. J. Nutr. $77: 897-909$ 


\section{APPENDIX}

The CCI is calculated using

$$
C C I=R H_{a d j}+W S_{a d j}+G S R_{a d j}
$$

from Mader et al. (2010), where

$$
\begin{gathered}
R H_{a d j}=e^{\left[(0.00182 \times R H)+\left(1.8 \times 10^{-5} \times T_{d b} \times R H\right)\right]} \times\left[\left(0.000054 \times T_{d b}^{2}\right)+\left(0.00192 \times T_{d b}\right)-0.0264\right] \times(R H-30) ; \\
W S_{a d j}=\left(\frac{-6.56}{\left.e^{(2.26 \times W S+0.23)^{0.45}}\right] \times\left[2.9+1.14 \times 10^{-6} \times W S^{2.5}-\log _{0.3}(2.26 \times W S+0.33)^{-2}\right]}\right)-0.0056 \times W S^{2}+3.33 ; \\
G S R_{a d j}=(0.0076 \times G S R)-\left(0.00002 \times G S R \times T_{d b}\right)+\left(0.00005 \times T_{d b}^{2} \times \sqrt{G S R}\right)+\left(0.1 \times T_{d b}\right)-2 .
\end{gathered}
$$

